\title{
Heterologous Protein Expression in Hypocrea jecorina: an Historical Perspective and New Developments
}

Arjun Singh ${ }^{1}$, Larry E. Taylor $\|^{2}$, Todd A. Vander Wall ${ }^{2}$, Jeffrey Linger ${ }^{1}$, Michael E.

Himmel $^{2}$, Kara Podkaminer ${ }^{2}$, William S. Adney², and Stephen R. Decker ${ }^{2}$

1 National Bioenergy Center

National Renewable Energy Laboratory

15013 Denver West Parkway

Golden, Colorado 80401

2 Biosciences Center

National Renewable Energy Laboratory

15013 Denver West Parkway

Golden, Colorado 80401

3 Corresponding Author: Stephen R Decker

Senior Scientist V

NREL

15013 Denver West Parkway

Golden, Colorado 80401

Steve.decker@nrel.gov

(303) 384-7759 


\section{Table of Contents}

TABLE OF CONTENTS 2

\begin{tabular}{lr} 
ABSTRACT & 3 \\
\hline
\end{tabular}

KEYWORDS 3

1. INTRODUCTION 3

2. HYPOCREA JECORINA AS AN EXPRESSION HOST $\quad 5$

2.1 HOST STRAINS FOR HETEROLOGOUS PROTEIN EXPRESSION

2.1.1 DELETION OF CBH1 FROM THE GENOME OF T. REESEI RUT-C30 8

2.1.2 DELETION OF CBH1 FROM THE GENOME OF T. REESEI QM6A 9

2.2 TRANSFORMATION AND SELECTION METHODS 9

2.2.1 PEG-MEDIATED DNA UPTAKE 10

2.2.2 AGROBACTERIUM-MEDIATED TRANSFORMATION 11

2.2.3 BIOLISTIC TRANSFORMATION

2.2.4 SPORE ELECTROPORATION

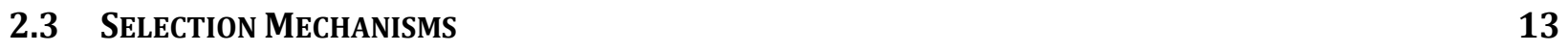

2.3.1 NitROGEN UTILIZATION

2.3.2 AUXOTROPHIC MUTANT COMPLEMENTATION 15

$\begin{array}{lll}2.3 .3 & 18\end{array}$

2.4 Control of Heterologous ExPRESSion ANd Production LeVElS 19

2.4.1 PROMOTER SELECTION 19

$\begin{array}{lll}2.4 .2 & \text { Site OF INTEGRATION } & 20\end{array}$

2.4.3 EFFECT OF Signal SEQUENCE

2.5
EXPRESSION OF RECOMBINANT CEL7A IN THE CBH1

3. CONCLUSIONS 25

4. ACKNOWLEDGMENTS 26 


\begin{abstract}
Hypocrea jecorina, the sexual teleomorph of Trichoderma reesei, has long been favored as an industrial cellulase producer, first utilizing its native cellulase system and later augmented by the introduction of heterologous enzymatic activities or improved variants of native enzymes. Expression of heterologous proteins in H. jecorina was once considered difficult when the target was an improved variant of a native cellulase. Developments over the past nearly 30 years have produced strains, vectors, and selection mechanisms that have continued to simplify and streamline heterologous protein expression in this fungus. More recent developments in fungal molecular biology have pointed the way toward a fundamental transformation in the ease and efficiency of heterologous protein expression in this important industrial host. Here, 1) we provide an historical perspective on advances in $H$. jecorina molecular biology, 2) outline host strain engineering, transformation, selection, and expression strategies, 3) detail potential pitfalls when working with this organism, and 4) provide consolidated examples of successful cellulase expression outcomes from our laboratory.
\end{abstract}

\title{
Keywords
}

Trichoderma reesei, Hypocrea jecorina, QM6a, Rut-C30, cbh1, Cel7A, cellobiohydrolase, cbh1 deletion, fungal transformation, cellulase expression systems

\section{Introduction}

Most cellulolytic enzymes used today in the biomass to biofuels or bioproducts industry are produced in the filamentous fungus, Hypocrea jecorina (Merino and Cherry, 2007). It is almost certain that for this industry, this organism will be the source for such hydrolytic enzymes in the foreseeable future. Originally isolated by Mary Mandels and Elwyn Reese 
from rotting cotton goods brought to the U.S. Army Quarter Master Research and Development Center at Natick, Massachusetts from the Solomon Islands during World War II, T. viride QM6a (as it was originally called, the "QM" designation is derived from Quarter Master) was soon demonstrated to be a prolific cellulase producer. Later, the parent $T$. viride species was shown to be distinctly different from $T$. viride and so it was renamed $T$. reesei in honor of its discoverer. Much later, it was determined to be a sexual anamorph of a well-characterized fungus, Hypocrea jecorina, though much of the current literature continues the use of T. reesei (Kuhls et al., 1996).

Beginning in the 1970s, several groups randomly mutagenized the parent QM6a strain, resulting in several hyper-producing strains including QM9414 (catabolite repressed, hyper-producer strain from Natick Labs) and RUT-C30 (catabolite derepressed, hyperproducer strain from Rutgers University) (Peterson and Nevalainen, 2012). The RUT-C30 strain formed the parent for all or nearly all commercial cellulase production strains of $T$. reesei (Seiboth et al., 2011). A more detailed lineage of strains developed for increased productivity has already been published and so this topic will not be expounded upon here (Seiboth et al., 2011). Although several genes encoding the hydrolytic enzymes from $H$. jecorina have been expressed in other organisms; for example, in yeasts (Boer et al., 2000, Boonvitthya et al., 2013, Den Haan et al., 2007, Godbole et al., 1999, Hong et al., 2007, Mitsuishi et al., 1990, Reinikainen et al., 1992, Takada et al., 1998), bacteria (Abdeljabbar et al., 2012, Laymon et al., 1996), and plants (Dai et al., 1999, Liu et al., 2004), the critical volumetric productivity levels required for cost effective cellulase deployment has been demonstrated only in fungi, with H. jecorina setting the bar at over $100 \mathrm{~g} / \mathrm{L}$ for certain protein expression scenarios (Cherry and Fidantsef, 2003). Furthermore, consistent attainment of native-like specific activity (performance) characteristics for $\mathrm{H}$. jecorina enzymes expressed in non-H. jecorina hosts has not been demonstrated.

There are several likely reasons for poor expression and/or activity levels observed for the heterologously expressed $H$. jecorina enzymes. One factor resides in differential protein glycosylation (Nevalainen and Peterson, 2014). It is known that protein glycosylation, both quantitative amounts and patterning, differs in yeast compared to filamentous fungi. Other 
critical post-translational modifications that differ are protease activity and $\mathrm{N}$-terminal processing of proteins. In addition, the Cel7A (cellobiohydrolase I from H. jecorina) fold is highly dependent upon di-sulfide bonds (specifically 10) for stability and many heterologous expression systems do not seem to be able to make the correct connections in this regard (Xu et al., 2014). While functional expression of Cel7A has been demonstrated in non-native fungal host strains, results have been mixed regarding activity and stability. Regardless, it is apparent that to ensure that the functionality of heterologous or genetically improved hydrolytic enzymes is accurately evaluated for properties in an appropriate production strain for the biomass conversion industry, engineered genes should ultimately be expressed in that strain, which is very likely to be H. jecorina.

Expression of heterologous proteins in H. jecorina has been carried out for several decades, beginning in 1987 when Pentillä et al. reported a basic transformation protocol for this fungus (Penttila et al., 1987). In this review, we will cover three main areas of Hypocrea molecular biology; 1) expression strains, 2) vector construction, and 3) selection protocols. Optimization of expression and biochemical characterization of the proteins will be left to other reviews, of which there are many. Recent reviews by Nevalainen et al. (Nevalainen $e t$ al., 2005), and Kruszewska (Kruszewska, 1999) cover much of the general protein expression knowledge base in filamentous fungi today. We will focus on heterologous cellulases, particularly Cel7A and engineered variants.

\section{Hypocrea jecorina as an Expression Host}

Aside from proprietary industrial strains used to produce enzymes at very high titers, multiple research laboratories have transformed T. reesei to express a variety of proteins, including both native and heterologous cellulases. When evaluating a system of heterologous expression, several criteria must be considered: the host strain, the transformation mechanism, the selective pressure, and control of expression.

\subsection{Host strains for heterologous protein expression}


For general heterologous protein expression, simple random integration into any strain with a given selection is the general approach and has been carried out for decades. Several strains have been developed with specific traits useful for protein expression, such as increased protein production and secretion, decreased protease activity, or specific gene knockouts (Table 1). Utilization of some of these strains was limited, as they were proprietary to industry or developed in-house by various academic labs. Many are no longer readily available; however, the properties developed (hyper-production, gene knock-out, auxotrophic selection, low protease) are found in some more modern strains and the published methodology makes re-creation of these strains fairly straightforward for labs with reasonable understanding of the technology.

In the 1970s, the Natick lab began mutational studies on QM6a, as did Eveleigh and Montenecourt at Rutgers. Both groups developed a series of mutated strains, eventually leading to QM9414 and RUT-C30, respectively (Montenecourt and Eveleigh, 1979, Peterson and Nevalainen, 2012). The RUT-C30 strain secretes large amounts of cellulases and synthesis of these enzymes is not repressed by glucose (Montenecourt and Eveleigh, 1979, Tangnu et al., 1981). It has been heavily engineered, resulting in large deletions of its genome, which is known to affect protein secretion and cellulase repression (Montenecourt and Eveleigh, 1979, Seidl et al., 2008, Tangnu et al., 1981). The QM6a strain produces a complete cellulase system when induced by cellulose, cellulose hydrolysis products such as cellobiose or cello-oligomers, or specific disaccharides, such as sophorose or lactose (Mandels et al., 1962, Sternberg and Mandels, 1979); however, cellulase production is severely inhibited by growth on glucose (Mandels and Reese, 1957, Nisizawa et al., 1972). While cellulase production can be repressed by growth on glucose (catabolite repression) in the parental QM6a strain and the hyper-producing QM9414 mutant strain of H. jecorina, the hyper-producing RUT-C30 strain is de-repressed and the native cellulase expression system is always "on," making separation and subsequent characterization of the heterologous protein from the native proteins extremely difficult, though productivity in RUT-C30 is generally higher than most other strains. 
In the 1980s and 1990s, several groups worked on developing $H$. jecorina strains for transformation, with VTT from Finland being the most prolific. Dozens of VTT-D-XXXXXXX strains were developed, with the VTT-D-79125 being the most commonly used starting point for further strain development; however, this strain and most of the others referenced in Table 1 no longer appear to be available from the VTT Culture Collection (http://culturecollection.vtt.fi). Properties of the VTT strains included hypercellulase activity/secretion, low protease, and gene knockout strains. VTT-D-79125 was also used to develop several ALKO-XXXX strains with similar properties, although very little information is available regarding these strains and the parent company, Alko, Ltd., which was, at the time, the Finnish government-owned alcoholic beverage supplier. In 1995, production of alcohol was separated from its distribution, creating Primalco, Ltd, which apparently maintained the ALKO strains. Later, Altia acquired Primalco and presumably the strains developed at Alko, Ltd as well. The authors have no idea if these strains still exist or are available.

Trichoderma strains deleted for cellulases are (apparently) widely used in industry; however, public information is very limited. Some publically disclosed deletion strains do exist, however. von Ossowski et al. used the cel7a/cel7b-double delete strain (ALKO 3414 from Primalco, Ltd.) to express mutant Cel7A proteins to better understand the exo-loop function in the protein (von Ossowski et al., 2003). Stahlberg et al. also utilized a cel7adelete strain, VTT-D-93201, to generate catalytically inactive mutants for crystallography studies. Several other groups have referenced using similar (or the same) strains; however, the details are not clear and the corresponding vectors are not readily available.

In response to a general lack of availability of strains and vectors, especially in the U.S., we recently developed transformation systems in QM6a and Rut-C30 specifically for studying cbh1 mutations by knocking out the native $c b h 1$ gene in each strain. Deleting the native cbh1 gene allowed Cel7A chimeras, improved mutant forms of Cel7A, and Cel7 enzymes from other sources to be expressed and evaluated without interference from the native Cel7A enzyme. QM6a was chosen because it is considered to be the "wild-type" strain of this fungus, having a presumably intact protein secretion, glycosylation, and post- 
translational modification system; as well as possessing a completely sequenced and published genome (Martinez et al., 2008). RUT-C30 was also chosen for our studies because it is an industrially relevant hyper-producer. Each of these strains has a single copy of the $c b h 1$ gene (Martinez et al., 2008). The $c b h 1$ gene in each strain was knocked out by replacement with either $h p h$ (for RUT-C30) or amdS (for QM6a); the reciprocal marker was used for the subsequent transformation with heterologous cbh1. Whereas both systems are functional, knocking out the QM6a native $c b h 1$ by replacing it with amdS made subsequent selection of heterologous $c b h 1$ insertion much easier using hygromycin resistance. The inverse strategy was used in case of RUT-C30, which rendered that system slightly more difficult to use due to the relatively poor selectivity of amdS vs. hygromycin resistance (see below).

\subsubsection{Deletion of $c b h 1$ from the genome of $T$. reesei Rut-C30}

We replaced the DNA coding for the Cel7A protein (cbh1) with the E. coli Hygromycin B phosphotransferase gene $(h p h)$, removing the capacity of the resulting strain to produce endogenous Cel7A. In the deletion cassette (Figure $1 \mathrm{~A}$ ), $h p h$ is driven by the $H$. jecorina pgk1 promoter and flanked by nucleotides homologous to 1492 bases upstream and downstream from the native $c b h 1$ sequence, providing homology on both sides of the Cel7A coding sequence in the genome, enhancing $c b h 1$ gene replacement frequency. The deletion cassette has XbaI endonuclease recognition sites at both ends, which permits the cassette to be excised from a carrier plasmid. A linear DNA fragment was then used to transform $H$. jecorina via PEG-mediated spheroplast DNA uptake and selection was carried out on 100 $\mu \mathrm{g} / \mathrm{mL}$ hygromycin B plates (details in transformation section below). After several rounds of sporulation and selection on hygromycin B media, transformants were screened for Cel7A by western blot and yielded a homologous recombination frequency of $\sim 5 \%$, with 2/44 clones showing no Cel7A expression. After PCR confirmation that the native cbh1 gene had been replaced by $h p h$, AST871 was selected for use as a host strain for heterologous $c b h 1$ expression.

Figure 1 near here 


\subsubsection{Deletion of $c b h 1$ from the genome of $T$. reesei QM6a}

The strategy used to delete cbh1 from QM6a was similar to that used for RUT-C30. The cbh1 gene was replaced with an expression cassette (Figure 1B) for the Aspergillus nidulans amdS gene, enabling growth on acetamide as the sole nitrogen source. This construct was designed to delete $c b h 1$ plus 1000 base pairs immediately preceding the $\operatorname{cbh} 1$ start codon to ensure that there would not be an additional promoter to the one included in the expression cassette. This deletion cassette can be excised with the restriction endonuclease site (KpnI) present only at both ends of the cassette for use as a linear DNA fragment for transformation. Transformants were selected on acetamide plates and screened by western blot for Cel7A expression. A single transformant, AST1116, was demonstrated to be deleted for $c b h 1$ and was selected for further heterologous expression work.

Several aspects of $H$. jecorina as well as the protein of interest must be considered when deciding on an expression host strain. What is the purpose of expression? That is, is the goal to get the highest yield, to study native folding/processing/secretion, to compare variants of the same protein, or to study the interaction between native enzymes and the heterologous protein? Depending on the intent, host strains may be off-the-shelf or may require genetic manipulation prior to use. In general, host strains are available from major culture collections, such as ATCC or have been developed by various commercial, governmental, or academic labs (Table 1). The latter tend to be specific phenotypes such as low protease, high productivity, or specific gene knockouts, however availability to the general research community is mixed.

Table 1 near here

\subsection{Transformation and selection methods}

Getting DNA into the transformation host, having it integrate and express, and isolating heterologous clones is carried out using several methods. Transforming H. jecorina is similar to many other filamentous fungi. A primary concern is the need to ensure single genome transformation, requiring either spores or single cells (usually protoplasts) to be separated from multicellular hyphae. Protoplast DNA uptake, Agrobacterium-mediated 
biolistics, and electroporation, approaches are all used. There are advantages and disadvantages to each system. The DNA can take several forms, including both circular or linearized plasmids; as well as PCR or restriction enzyme fragments. The older methodology of using multiple constructs, i.e., one containing the selection marker and another the gene of interest is still a reasonable approach, although modern DNA synthesis and cloning methods allow much simpler and less expensive vector constructs, where multiple genes can be included on a single vector. Whereas circular plasmid DNA is also still viable, our experience is that linearized vectors provide much higher transformation efficiency. Others have reported transient expression with circular plasmids, as they apparently autonomously replicate for a period of time before being lost (Smith et al., 1991). Another observation is that incubation of transformation plates under light enhances sporulation, which while generally well known (keeping bread in a dark breadbox), is frequently overlooked.

\subsubsection{PEG-mediated DNA uptake}

Historically, fungal protoplasts (complete removal of cell wall) have been used to passively uptake DNA in the presence of high levels of polyethylene glycol (PEG) of various high molecular weights. The earliest reports of Hypocrea transformation utilized PEG-mediated DNA uptake, as it had already been shown to work for other fungi. During PEG-mediated transformation, Hypocrea jecorina cell walls are digested with a cell lysing mix of enzymes in the presence of osmotic stabilizers to prevent the fragile cells from lysing due to osmotic differences. Heterologous DNA is introduced at fairly high levels and it is integrated into the genome. PEG-mediated transformation is fairly time consuming, as cell wall digestion must be done slowly and carefully to maintain cellular integrity. The starting cells should be freshly grown from frozen spore stocks and several wash steps are involved to remove spores and cell wall debris. It also requires fairly large amounts of DNA, typically 1 to $5 \mu \mathrm{g}$ for each transformation, and the efficiency is low. Additionally, the fragility of the protoplasts contributes to a high mortality, as they must deal with shear, osmotic, and thermal stresses that often lyse the fragile cells. 
Briefly, DNA is propagated on a suitable vector, typically an E. coli plasmid, purified, and suspended at a concentration of several $\mathrm{mg} / \mathrm{mL}$. Hypocrea jecorina spores are grown in a rich medium until reasonable hyphae are formed. The hyphal mass is recovered by filtration, washed, and suspended in a protoplasting buffer with osmotic stabilizers such as sorbitol, $\mathrm{KCl}$, or $\mathrm{MgCl}_{2}$. A cell-wall lysing mixture is added, often a commercial Trichoderma harzianum prep (such as Novozyme 234) with high chitinase and $\beta$-glucanase activity. After digestion for several $\mathrm{h}$ to overnight, the undigested cell wall material is removed by filtration; the protoplasts are then separated by mild centrifugation and gently resuspended in $25-60 \% \mathrm{PEG}+\mathrm{CaCl}_{2}+\mathrm{DNA}$. Unused protoplasts can be frozen at $-70^{\circ} \mathrm{C}$; however, the transformation efficiency decreases by $50 \%$ (Penttila et al., 1987). After incubation (room temp or $4^{\circ} \mathrm{C}$ ), aliquots of the transformation mix is suspended in molten osmotically-stabilized top agar, gently mixed, and poured over a selection plate. After several days, colonies form, which are then picked, passed several times on selection medium, and then screened for the desired protein.

Obviously, many things can go wrong during the generation of the protoplasts and yield poor results. The time and high levels of DNA required make this method somewhat cumbersome and inefficient; however, it is a relatively simple procedure and can be accomplished by laboratories with limited resources.

\subsubsection{Agrobacterium-mediated transformation}

Agrobacterium tumefaciens is a soil microbe capable of transferring DNA directly into the cells of plants and fungi. Use of Agrobacterium requires a plasmid vector with specific transfer sequences bracketing the DNA for insertion. The vector-containing Agrobacterium cells are mixed with either Hypocrea protoplasts or conidia in a suitable medium, incubated for infection to occur, and then plated onto a selective medium capable of killing the Agrobacterium cells (Ma et al., 2011, Meng et al., 2013). Agrobacterium-mediated transformation efficiency is much higher ( $\sim 10$ to $50 \mathrm{X})$ for protoplasts compared to conidia, although the process required to generate the protoplasts obviously complicates the method (Zhong et al., 2007). Other complicating factors include the requirement for 
separate transformation events for the bacteria and the fungi, and killing the bacterial cells post-transformation.

\subsubsection{Biolistic transformation}

Biolistics transformations in fungi is reportedly lower in efficiency than protoplast uptake (Hazell et al., 2000), although Te'o et al reported approximately 35 to 40 transformants/ $\mu \mathrm{g}$ of plasmid DNA (linear or circular) using T. reesei (Te'o et al., 2002). In biolistics procedures, heterologous DNA is coated onto high-density microparticles (usually gold or tungsten), which are then "fired" into cells or spores using high-pressure helium. The DNAcoated particles are coated onto the underside of a rupture disk that is placed above the target cells or spores already spread onto a selective agar plate (Hazell et al., 2000). The system between the rupture disk and target cells is placed under a vacuum or partial vacuum and the helium pressure above the rupture disk is increased until the disk ruptures, accelerating the particles towards the target cells. Rupture disks are available at different pressure ratings and this factor must be balanced with size and density of the microparticles, the level of vacuum, and the distance between the disk and target plate in order to achieve good transformation efficiency. In essence, the particles must be traveling with enough velocity to penetrate the spore coat, cell wall, cell membrane, and/or nuclear membrane (depending on target cell type), but not so fast that they exit the cell. This procedure is highly variable based on cell types, although conditions for many have been worked out (Te'o et al., 2002).

The advantages of biolistics are primarily the ease of use and high co-transformation efficiency. Particles are relatively easy to prepare and the use of spores instead of protoplasts makes target cell preparation very simple. When multiple genes are coated onto the same microparticle, co-transformation frequency exceeds 90\%, presumably because a successful insertion of a microparticle carries both genes, eliminating the need for separate uptake and transport events when other transformation mechanisms are used (Hazell et al., 2000). The disadvantages are mainly the need for specialized equipment and low transformation efficiency, although the requirement to empirically work out the optimal parameters for new cell types may be another consideration. 


\subsubsection{Spore electroporation}

Perhaps the most promising route of delivering DNA to T. reesei is through the use of spore electroporation for its ease, efficiency and reduced hands-on-time. Initial descriptions of methods to electroporate can be found in a patent application filed in 2008 by Danisco U.S., Inc. Genencor Division(Kim and Miasnikov, 2010). Additionally, this protocol was adapted and a direct comparison was recently made between protoplasting and electroporation. The results suggest similar efficiencies between the two methods but that electroporation was, in general, a simpler method (Schuster et al., 2012a). It has been noted that transformation via electroporation at least using hygromycin-resistance cassettes leads to two distinct colony size distributions (Linger et al in preparation). Larger colonies tend to be true transformants and smaller colonies tend to be only transiently resistant to hygromycin. We note this finding as it reduces the likelihood of false-positive clone selection following electroporation.

In essence, spore-electroporation protocols involve harvesting fresh spores, washing, and suspending in a sorbitol solution. DNA is then added to the mix and electroporated. Spores are allowed ample time to recover and germinate prior to being plated onto selective medium. Regarding optimal electroporation conditions, it seems that this remains somewhat of a moving target. For example, in January of 2012, electroporation conditions were reported as $1.8 \mathrm{kV}, 800 \Omega$, and $25 \mu \mathrm{F}$ (Schuster et al., 2012a). However, in April of 2012 the same group used slightly different conditions $1.8 \mathrm{kV}, 600 \Omega 10 \mu \mathrm{F}$ (Schuster et al., 2012b). While there is certainly success along this front, there lacks a clear publication surrounding the variables of $T$. reesei spore electroporation, and which conditions are likely to garner the highest transformation efficiency. Moving forward, an important data set will be the complete optimization of electroporation conditions surrounding numerous variables including: spore age, spore density, electroporation medium, voltage, internal resistance of the power supply, capacitance, DNA concentration, outgrowth medium, and outgrowth time.

\subsection{Selection Mechanisms}


Multiple selection mechanisms have been used with H. jecorina, with nitrogen utilization, auxotroph complementation, and antibiotic resistance being the most common. Although split marker systems, which require homologous recombination between separate (i.e. split) selection marker sections, have been used in yeast and filamentous fungi to enhance selection, this has not been demonstrated in H. jecorina (Kuck and Hoff, 2010, Steiger, 2013).

\subsubsection{Nitrogen utilization}

One of the most widely used selection mechanisms in H. jecorina transformation is growth on acetamide as a sole nitrogen source (Bailey et al., 2002, Harkki et al., 1991, Hazell et al., 2000, Joutsjoki et al., 1993b, Karhunen et al., 1993, Miettinen-Oinonen et al., 1997, Nykanen et al., 1997, Penttila et al., 1987, Saarelainen et al., 1997, Saarelainen et al., 1993, Schuster et al., 2012a, Suominen et al., 1993, Te'o et al., 2000). Wild-type $H$. jecorina lacks the acetamidase gene (amdS) that cleaves acetamide into acetic acid and ammonium. The addition of an amdS gene (usually from Aspergillus spp.) enables $H$. jecorina to grow on acetamide as a sole nitrogen source, and as such, is one of the few non-antibiotic-based dominant selection mechanisms available for $H$. jecorina molecular biology. Selection is carried out using a minimal medium with a carbon source of choice and acetamide as the sole nitrogen source. Selection has been shown to be enhanced with $\mathrm{CsCl}$ and agarose (Penttila et al., 1987).

\subsubsection{Expression vector for cbh1 $\Delta$ strain AST871}

We recently developed an expression vector, shown in Figure 2, for expressing various genes in the RUT-C30-based deletion strain described above. As the deletion strain was already resistant to hygromycin B from the cbh1 deletion, we used Aspergillus nidulans $a m d S$ as a secondary marker utilizing acetamide as the sole nitrogen source (Berges and Barreau, 1991). The expression of the amdS gene is controlled by the T. reesei pgk1 promoter. This vector contains $c b h 1$ promoter followed by the transcription termination signal (trpC) from A. nidulans. The DNA encoding proteins to be expressed is inserted between the unique $\mathrm{NdeI}$ and $\mathrm{XbaI}$ endonuclease sites. 
Figure 2 near here

\subsubsection{Auxotrophic mutant complementation}

Auxotrophic mutants lack the ability to synthesize a specific compound needed for viability. When cultured, the specific compound must be added to the medium in order to allow the cells to grow. As a selection method, auxotrophs are usually generated by spontaneous or random mutation, resulting in the inactivation of one or more genes in a specific biosynthetic pathway. The selection of auxotrophic mutants can be very tedious, as randomly mutagenized strains must be screened for growth in the presence and absence of the target compound on minimal media. Alternatively, a toxic analog can be used to poison cells still capable of synthesizing the target compound, allowing only auxotrophic mutants to grow on media containing the target compound and toxic analogue.

Once an auxotrophic strain is generated and confirmed, transformation proceeds by one of the aforementioned methods. A complementary gene that re-enables prototrophy (the ability to synthesize the needed compound) is co-transformed along with the target gene and cells are selected on minimal medium in the absence of the target compound. If a toxic analogue is available, it can be used to revert the strain auxotrophy by reselection on media containing the target compound and the toxic analogue. In this way, auxotrophy can be used a means to recycle a selection marker, enabling multiple genes to be transformed into a single strain using the same selection marker. In H. jecorina, two compounds are the most widely targeted for auxotrophy; arginine and uridine.

Ornithine carbamoyl transferase $(\arg B)$ is required for arginine synthesis (Penttila et al., 1987). For $\arg B$ auxotrophs in H. jecorina, $A$. nidulans $\arg B$ is often used to complement the strain back to prototrophy. Growth of the co-transformed auxotroph on minimal medium without arginine is the means of selection.

Uridine auxotrophs require uridine or uracil in the medium in order to grow, although uracil is used most frequently as it is inexpensive and convenient. Several mutations in the uridine biosynthesis pathway can cause uridine auxotrophy with orotidine 5'monophosphate decarboxylase (ura3/pyr4/pyrG, depending on the organism) (Deane et al., 
1999, Gruber et al., 1990, Smith et al., 1991) or orate phosphorybosyltransferase (ura5) (Berges and Barreau, 1991) being the most common. Typically, pyr4 from Neurospora crassa or pyrA from Aspergillus niger are used to select transformation on minimal ura(-) medium. Spontaneous mutations occur frequently in these genes, making it relatively easy to generate an auxotrophic strain, but also allowing reversion to occur, so strains must be screened carefully to ensure the target gene is present. Interruption or deletion of the gene, rather than simple mutation is preferred for this reason. Native ura3/ura5 have high efficiency of complementation. More recently, Jørgensen et. al. developed a recyclable and targeted system using a pyr 2 auxotroph of a $t k u 70$ delete strain of H. jecorina. The $t k u 70$ deletion enhances targeted insertion, in this case into the ade2 locus of the genome, providing the additional advantage of targeted insertions causing a red pigment formation in transformed cells(Jorgensen et al., 2014).

5-fluoroorotic acid (5-FOA) is a metabolic analogue that, when cleaved by orotidine 5'monophosphate decarboxylase in the uridine biosynthesis pathway, generates 5fluorouracil, a toxin that kills the host cell (Steiger et al., 2011). Inclusion of 5-FOA in uracilcontaining media will kill strains with the complete uridine anabolic pathway, but allow spontaneous auxotrophic revertants to grow, thus allowing marker recycling in transformed strains, as long as the plasmid has integrated into the genome. Hartl and Seiboth utilized 5-FOA as a counter selection mechanism of a pyr4 blaster cassette as a recyclable marker to sequentially delete glucokinase and hexokinase from $\mathrm{H}$. jecorina (Hartl and Seiboth, 2005). To encourage marker excision during counter selection, repeat flanking regions are often included on either side of the marker. Direct repeats allow for seamless removal of the inserted sequence while inclusion of random repeats can leave extraneous DNA behind in the sequence.

One case has demonstrated the use of mannitol as a sole-carbon source allows for selection when hexokinase ( $h x k 1)$ is deleted from the genome and then used as an autotrophic marker (Guangtao et al., 2010). An advantage of this system is that the mannitol used as an osmotic stabilizer during Agrobacterium-mediated transformation of protoplasts is also the selection pressure. 


\subsubsection{Generation of a recyclable auxotroph with NHEJ}

In practical terms, we have utilized pyr4 deletion coupled with 5-FOA selection and removal of the hygB selection marker to establish a recyclable marker system in H. jecorina. To use the entire pyr4 cassette as marker, the native copy was first deleted (Steiger et al., 2011). A vector was constructed fusing the regions directly upstream and downstream of the cassette, preventing future homologous recombination at this site. This vector was transformed into the QM6a (hygB::tmus53) strain and colonies were selected in the presence of 5-FOA (Figure 3a). Confirmation of the pyr4 deletion was confirmed both by PCR (Figure $3 b$ ) and sequencing.

Figure 3 near here

Initial efforts were unable to isolate a pyr4 deficient strain from background growth in the presence of 5-FOA. Both in the untransformed control and the test plate, yellow mycelia and distinct colonies grew (Figure 4a, b). However, 5-FOA is active only at acidic pH. Thus, by lowering the $\mathrm{pH}, 5-\mathrm{FOA}$ enters the cell and reduces background growth for a distinct selection (Figure 4c, d).

Figure 4 near here

In order to remove the hygB cassette at the tmus53 locus and demonstrate the recyclability of the pyr4 marker cassette, the following vector was transformed into the QM6a(hygB::tmus53 spyr4) strain. The first step inserted the pyr4 cassette and the corresponding flanking regions at the tmus53 locus through a selection on MA medium without uradine (Figure 5a).

Figure 5 near here

Subsequent loss of the pyr4 cassette was the selected for by plating on MA with 5-FOA, looping out at the repeated tmus53 DOWN regions (Figure 5b, top). The result is a clean deletion at the tmus53 locus (Figure 5b, bottom). Deletion of the hygromycin marker cassette was confirmed by PCR (Figure 6) and sequencing. The resulting strain, QM6a(stmus53spyr4), is a uridine auxotroph that is sensitive to hygB, thus recycling both 
markers for future use. This new strain allows gene deletions, promoter swaps, better expression control, reduced variability, and insertion of multiple genes with marker recycle.

Figure 6 near here

\subsubsection{Antibiotic resistance}

Two antibiotics are commonly used as selection markers in H. jecorina; phleomycin from Streptoallotheicus hindustanus (Harkki et al., 1991) and hygromycin (hph) from E. coli (Bailey et al., 2002, Hazell et al., 2000, Herrera-Estrella et al., 1990, Mach et al., 1994,

Steiger et al., 2011, Te'o et al., 2002, Te'o et al., 2000). We have also noticed that Hypocrea jecorina strains that we have tested appear to be poorly selected by Zeocin, the most common form of phleomycin. In our experience, hygromycin is more selective and results in very low background. We note that pyrithiamine ( $p$ trA) (Kubodera et al., 2002) has also been used.

\subsubsection{Expression vector for cbh1 $\Delta$ strain AST1116}

We designed and constructed the expression vector, pTR50 (Figure 7) for expression of various cellobiohydrolases and other proteins in the T. reesei strain AST1116. This vector contains the E. coli hph gene whose expression is controlled by the T. reesei pgk1 promoter, and thus provides for selection of transformants by conferring resistance to hygromycin $\mathrm{B}$. It contains a $c b h 1$ promoter followed by $c b h 1$ coding sequence, without introns and $c b h 2$ transcription termination signals. The NdeI/XbaI cbh1 coding sequence can be replaced with other genes for expression. The entire expression cassette can be excised by digestion with restriction endonuclease XhoI and used for transformation of AST1116. The transforming DNA fragment has homologies to $c b h 15^{\prime}$ and $3^{\prime}$ flanking regions to increase the frequency of integration of the expression constructs at the $c b h 1$ locus in the genome. Note that a large (2500 bp) $c b h 1$ promoter is used in this construct to provide for sufficient cbh1 homology at the 5 ' end and that $1000 \mathrm{bp}$ of the sequence immediately preceding the cbh1 start codon has been deleted in AST1116 (Figure 7). This cassette was designed to be 
used as a random-integration vector as it does not contain paired 5' and 3' targeting homology.

Figure 7 near here

\subsection{Control of Heterologous Expression and Production Levels}

Expression of heterologous proteins in filamentous fungi is a major obstacle in industrial enzyme production and many factors are involved. Koushki et al. has summarized these concerns in a mini-review (Koushki et al., 2011); however, here we point out specific examples and applications concerning $H$. jecorina relevant to our work.

\subsubsection{Promoter Selection}

The primary means of expression control is the choice of promoter. Whereas the native cbh1 promoter is inducible and the most commonly used for high expression levels, it has the distinct disadvantage of being tied to the rest of the cellulase system (Bailey et al., 2002, de Faria et al., 2002, Fang and Xia, 2013, Harkki et al., 1991, Joutsjoki et al., 1993b, Karhunen et al., 1993, Miettinen-Oinonen et al., 1997, Nykanen et al., 1997). Similarly, the cbh2, xyn2, and egl2 promoters have also been used individually and in series (Meng et al., 2013, Miyauchi et al., 2013, Miyauchi et al., 2014). The cbh1 promoter has also been shown to increase expression when multiple copies are used to drive expression (Liu et al., 2008, Zhang et al., 2010). Inducers of cbh1 and other cellulase gene promoters invariably induce other cellulases and/or hemicellulases, resulting in a very complex mix of secreted proteins that often have similar or identical activities to that of the heterologous gene. To circumvent this, constitutive promoters such as rp2 (He et al., 2013), pgk1 (Keranen and Penttila, 1995), pki (Keranen and Penttila, 1995, Mach et al., 1994), tef1 (Keranen and Penttila, 1995, Uzbas et al., 2012), gpd (Penttila et al., 1987, Zhang et al., 2012), cdna1 (Uzbas et al., 2012), pdc (Li et al., 2012, Wang et al., 2014), and eno (Li et al., 2012), have been used. There has also been work in modifying the cbh1 promoter to remove the glucose repression effects, resulting in mutant $c b h 1$ promoters with high inducibility when grown on glucose (Liu et al., 2008, Zou et al., 2012). Deletion of the primary transcriptional 
activating factor, $x y r 1$, also has been shown to allow heterologous protein production in an essentially cellulase-free background when using the $c b h 1$ promoter (Uzbas et al., 2012).

The use of the cbh1 promoter has been shown to have its downsides. Qin et al. clearly showed that heterologous lipase production by the $c b h 1$ promoter was enhanced when Cel7A translation was inhibited by RNAi (Qin et al., 2012). Expression of a heterologous endochitinase was proportionally reduced when multiple copies were inserted, presumably due to a lack of transcription and/or regulatory elements caused by multiple copies of the strong $c b h 1$ promoter (MargollesClark et al., 1996).

The selection of constitutive promoters often leads to reduced levels of expression compared to a strong cellulose promoter. For research purposes; however, purification of target proteins from a cellulase free broth is often viewed as more desirable than working with a high cellulase background, even if the targeted protein is in higher titer. Historically, Nakari-Setälä et al reported in 1995 the development of a modified strain of T. reesei able to grow on glucose, where catabolic repression shuts down the normal cascade of cellulase expression, that produced targeted proteins using novel promoters (Nakari-Setala and Penttila, 1995). This early step in engineering promoter performance led the field toward engineered T. reesei strains that were able to secrete heterologous genes into the culture medium without the high background interference from other cellulases. Today, much of the work on promoter selection and engineering in T. reesei remains sequestered behind industrial firewalls.

\subsubsection{Site of Integration}

Protein production levels are also influenced by other factors, primarily site of genome integration and integrated gene copy number. Increased integrated copy number has been shown to lead to increased protein production in some cases (Bailey et al., 2002, Levasseur et al., 2006, Liu et al., 2008, Miettinen-Oinonen and Suominen, 2002), but not in others (Miyauchi et al., 2013). The site of integration is also known to influence protein expression and can provide other advantages, such as visual confirmation of correct insertion by red pigment production when the ade2 locus is targeted (Jorgensen et al., 
2014). Targeting heterologous genes to the cbh1 locus has resulted in high expression levels; however, other factors, such as the use of the cbh1 promoter has complicated a direct correlation in one case (Karhunen et al., 1993). Another case clearly showed that targeted insertion of a glucoamylase gene from Hormoconis resinae into the cbh1 locus yielded 3-fold higher production than the same gene randomly inserted in triplicate in the genome (Joutsjoki, 1994). This work was complicated by the use of gDNA for the targeted insertion and cDNA for the random insertion; however, both DNA forms gave folded and active protein, indicating that intron processing was carried out correctly for the heterologous gDNA. Saarelainen et al. used three strains of T. reesei as hosts for xyn2 expression under its own promoter. Strains that had the xyn2 gene targeted to the cbh1 locus showed slightly lower xyn2 expression levels; however, copy number in the random insertion transformants was proposed to be a probable cause for this effect (Saarelainen et al., 1993). Whereas targeted insertion in H. jecorina has been facilitated by long sequenceidentical arms flanking the heterologous gene followed by tedious analysis by Southern blotting or PCR, the development of Non-Homologous End-Joining (NHEJ) mutants has opened up this area by increasing the efficiency of targeting to $>90 \%$. The most common mechanism of generating NHEJ mutants is the deletion of either $t k u 70$ or mus53 (Guangtao et al., 2009, Mustalahti et al., 2013, Schuster et al., 2012a, Steiger et al., 2011).

In our work, we generated a NHEJ mutant through the deletion of tmus53 in $\mathrm{H}$. jecorina QM6a. The native copy of tmus53 was replaced by a hygromycin B cassette as shown in Figure 8a. After selection on hygB, targeted insertions were screened by PCR, where a shorter PCR product indicates targeted insertion. (Figure 8b, c) Positive transformants were further purified and verified for the targeted deletion by sequencing.

Figure 8 near here

\subsubsection{Effect of Signal Sequence}

The choice of signal sequence (de Faria et al., 2002) and fusion to known high-expression domains has also been demonstrated to increase yield in $H$. jecorina, although as with most studies, multiple factors, such as site of integration, copy number, and promoter 
complicate the interpretation. One study using the same locus and single copy number of the same gene did show that signal sequence could affect protein production levels (Joutsjoki et al., 1993a). Another study demonstrated that the GC content of the signal sequence could be altered to improved productivity without changing the amino acid sequence (Li et al., 2007). Additional work in fusion proteins has indicated that fusion of heterologous protein sequences to native $H$. jecorina coding sequences can also increase expression yields (Nyyssonen et al., 1993).

As with many filamentous fungi, protease production is a major concern for protein production in H. jecorina (Dienes et al., 2007). Deletion of certain proteases has been shown to increase yields for several proteins (Zhang et al., 2014); however, others are required for correct processing of native enzymes (Goller et al., 1998). Moreover, it is generally known that lowering the culture $\mathrm{pH}$ increases proteolytic activity in $H$. jecorina, due to the activity characteristics of acidic aspartate proteases, although this effect is likely mediated by the presence of glycosylation on the target proteins (Eneyskaya et al., 1999). Despite these examples, there is relatively little information available regarding the effects of protease inhibition or deletion on the expression and yield of heterologous proteins in $H$. jecorina.

Fusion proteins, in which a native $H$. jecorina protein or protein domain is genetically linked to the target gene, has been used to successfully express heterologous proteins. It has been shown to enable expression and increase protein yield; as well as to simplify purification. Mustalahti et al. recently showed that fusion of target proteins to the hydrophobin domain resulted in large segregated protein bodies that could be readily separated using a 2-phase aqueous extraction (Mustalahti et al., 2013). Also, a bacterial xylanase gene (Nonomuraea flexuosa xyn11A) was expressed at high levels when fused to native $H$. jecorina Man5A core-hinge or Cel6A-CBM domains (Paloheimo et al., 2003). While a direct comparison to the non-fusion gene was not carried out, the Thermomonospora fusca $t f x A$ gene, $90 \%$ homology to xyn11A, expressed very poorly when used alone. Conversely, expression of a heterologous fungal xylanase (XynII from Humicola grisea) was reduced when fused to the Cel7A core-linker domain, even though the fusion 
protein was shown to be processed correctly, resulting in a native-like XynII protein being produced (de Faria et al., 2002).

Codon optimization is often cited as a means to increase expression of heterologous protein. Unfortunately, while H. jecorina genes have been optimized for expression in other hosts, there are very few examples of the inverse, especially when compared to the native gene sequence. Te'o et al. demonstrated dramatically increased functional expression of a $x y n B$ gene from a thermophilic bacterium after optimizing 20 codons for expression in $H$. jecorina and fusing the gene to a host carrier protein sequence (Bergquist et al., 2004, Te'o et al., 2000). When they expressed a heterologous fungal xylanase, codon optimization was not required, nor was fusion to a native carrier sequence (Bergquist et al., 2002). More recently, Poldevin et al. expressed an optimized Piromyces gene in H. jecorina; however, they did not attempt expression of the native gene sequence (Poidevin et al., 2009). Xin and Jia made similar claims using an Orpinomyces $\beta-1-4$ endoglucanase (Jin and Xia, 2011). Although protein expression was high using the codon-optimized gene, they did not test expression of the non-optimized gene.

Finally, whereas transient protein expression has been reported from non-integrated plasmids, this result is typically low expression and short-lived, resulting in rapid loss of the selection marker and subsequent loss of the strain.

\subsection{Expression of recombinant Cel7A in the cbh1 $\Delta$ strains}

We demonstrated the utility of the two deletion strains, AST871 and AST1116, generated from Rut-C30 and QM6a, respectively, by transforming these strains with the appropriate expression vectors described above. As shown in Figure 9, the transformed strains, RutC30, and QM6a, produce Cel7A. We have also tested the deletion strains for synthesis of other cellulases ( $c b h 2$ and egl1) and found that both deletion strains produce these enzymes at levels similar to the parent strains from which the deletion strains were derived.

Figure 9 near here 
The Cel7A expression cassette in pTR50 has been designed such that integration of the expression system may be directed to $c b h 1$ locus by homologous recombination between the 5' and 3' regions of the cbh1 region in the expression cassette and the corresponding regions in the AST1116 host strain. It is expected that the frequency of such events in AST1116 would be low. In approximately 5\% of the transformants obtained in the experiments to delete the cbh1 coding sequence from QM6a, the deletion cassette had integrated at the target and these constructs had $1.5 \mathrm{~kb}$ homology at 5' and 3' ends. We note that the frequency of homologous recombination, and thus of targeting, can be increased by deleting one of the genes, e.g., tku70, that are required for the ectopic DNA integration by the non-homologous end joining (NHEJ) pathway (Guangtao et al., 2009).

Even with the presence of the NHEJ pathway in AST1116, a transformant in which the integration event has occurred by homologous recombination at the cbh1 locus can be distinguished from other transformants because of the characteristic phenotypes of these two classes of the transformants as shown in Figure 10. The parent strain does not utilize acetamide because it does not contain the A. nidulans amdS gene and it is sensitive to hygromycin B because it does not contain the E. coli hph gene. The deletion strain; however, utilizes acetamide, but is still sensitive to hygromycin B. If the expression cassette integrated at the $c b h 1$ locus by homologous recombination, this genomic region would have the structure shown in the bottom of the Figure 10. This transformant would now be resistant to hygromycin B and could no longer utilize acetamide as nitrogen source because the amdS gene would be lost. If the integration event happens elsewhere in the genome, the transformants would retain the expression of amdS and thus still be able to utilize acetamide. The acetamidase-expressing strains can be further distinguished by their sensitivity to the analogue fluoroacetamide (Hynes and Pateman, 1970, Steiger et al., 2011).

Figure 10 near here 


\section{Conclusions}

There are a large number of Hypocrea jecorina strains that have been used to express heterologous proteins for a variety of reasons. Many of these strains, particularly those that have specific genes or capabilities deleted or added, were never available to the public or are no longer used by academic labs. Modern molecular biology methodologies make it relatively straightforward for competent labs to recreate these strains and their associated vectors; however, it is incumbent upon these researchers to consider several criteria before embarking on this work. Specifically, they must consider the exact nature of the desired outcome, such as mutational studies of a specific protein, increased productivity, or structure/function studies of particular enzymes or enzyme classes. From this set of criteria, they can then select the appropriate host strain and tools to achieve that outcome. Host strain, selection markers, gene modification (codon optimization, fusion protein, promoter and signal sequence selection), copy number, insertion locus, and protease abatement all impact heterologous gene expression differently under variable

circumstances. Some general guidelines emerge from the published record: proteins difficult to express in $H$. jecorina include those that are multi domain, require specific glycosylation, and/or are bacterial in origin. Note that exceptions exist, but these trends seem to hold.

To support biofuels research funded by the U.S. Department of Energy, we have developed expression hosts and the corresponding vectors for two T. reesei strains, the wild type strain, QM6a, and industrial "work horse" Rut C-30 specifically for expressing $c b h 1$ variants and mutations. We have replaced the $c b h 1$ genes in QM6a and in Rut C-30 with A. nidulans amdS and E. coli hygromycin B phosphotransferase genes, respectively; and developed expression vectors for inserting heterologous genes into these strains. The deletion strains are able to produce functional Cel7A proteins when DNA constructs encoding these proteins are reintroduced. These new T. reesei systems are suitable for production of 1 ) improved forms of cellulases by rational design or random mutagenesis, 2) diverse natural enzymes for phylogenetic studies, and 3) native enzymes with critical mutations designed to study biochemical modes of action. 


\section{Acknowledgments}

This work was supported by the U.S. Department of Energy under Contract No. DE-AC3608G028308 with the National Renewable Energy Laboratory. Funding for the work was provided by the DOE Office of Energy Efficiency and Renewable Energy, Bioenergy Technologies Office.

\section{References}

Abdeljabbar DM, Song HJ, Link AJ. Trichoderma reesei cellobiohydrolase II is associated with the outer membrane when overexpressed in Escherichia coli. Biotechnology letters. 2012;34:91-6.

Bailey MJ, Askolin S, Horhammer N, Tenkanen M, Linder M, Penttila M, et al. Process technological effects of deletion and amplification of hydrophobins I and II in transformants of Trichoderma reesei. Applied microbiology and biotechnology. 2002;58:721-7.

Berges T, Barreau C. Isolation of uridine auxotrophs from Trichoderma reesei and efficient transformation with the cloned ura3 and ura5 genes. Current genetics. 1991;19:359-65.

Bergquist P, Te'o V, Gibbs M, Cziferszky A, de Faria FP, Azevedo M, et al. Expression of xylanase enzymes from thermophilic microorganisms in fungal hosts. Extremophiles : life under extreme conditions. 2002;6:177-84.

Bergquist PL, Te'o VS, Gibbs MD, Curach NC, Nevalainen KM. Recombinant enzymes from thermophilic micro-organisms expressed in fungal hosts. Biochemical Society transactions. 2004;32:293-7.

Boer H, Teeri TT, Koivula A. Characterization of Trichoderma reesei cellobiohydrolase Cel7 A secreted from Pichia pastoris using two different promoters. Biotechnology and bioengineering. 2000;69:486-94.

Boonvitthya N, Bozonnet S, Burapatana V, O'Donohue MJ, Chulalaksananukul W. Comparison of the heterologous expression of Trichoderma reesei endoglucanase II and cellobiohydrolase II in the yeasts Pichia pastoris and Yarrowia lipolytica. Molecular biotechnology. 2013;54:158-69.

Cherry JR, Fidantsef AL. Directed evolution of industrial enzymes: an update. Current opinion in biotechnology. 2003;14:438-43. 
Dai Z, Hooker BS, Quesenberry RD, Gao J. Expression of Trichoderma reesei exocellobiohydrolase I in transgenic tobacco leaves and calli. Applied biochemistry and biotechnology. 1999;77-79:689-99.

de Faria FP, Te OV, Bergquist PL, Azevedo MO, Nevalainen KM. Expression and processing of a major xylanase (XYN2) from the thermophilic fungus Humicola grisea var. thermoidea in Trichoderma reesei. Letters in applied microbiology. 2002;34:119-23.

Deane EE, M. WJ, Peberdy JF. Transformation of Trichoderma reesei with a constitutively expressed heterologous fungal chitinase gene. Enzyme and microbial technology. 1999;24:419-24.

Den Haan R, McBride JE, Grange DCL, Lynd LR, Van Zyl WH. Functional expression of cellobiohydrolases in Saccharomyces cerevisiae towards one-step conversion of cellulose to ethanol. Enzyme and microbial technology. 2007;40:1291-9.

Dienes D, Borjesson J, Hagglund P, Tjerneld F, Liden G, Reczey K, et al. Identification of a trypsin-like serine protease from Trichoderma reesei QM9414. Enzyme and microbial technology. 2007;40:1087-94.

Eneyskaya EV, Kulminskaya AA, Savel'ev AN, Savel'eva NV, Shabalin KA, Neustroev KN. Acid protease from Trichoderma reesei: limited proteolysis of fungal carbohydrases. Applied microbiology and biotechnology. 1999;52:226-31.

Fang H, Xia L. High activity cellulase production by recombinant Trichoderma reesei ZU-02 with the enhanced cellobiohydrolase production. Bioresource technology. 2013;144:693-7.

Godbole S, Decker SR, Nieves RA, Adney WS, Vinzant TB, Baker JO, et al. Cloning and expression of Trichoderma reesei cellobiohydrolase I in Pichia pastoris. Biotechnology progress. 1999;15:828-33.

Goller SP, Schoisswohl D, Baron M, Parriche M, Kubicek CP. Role of endoproteolytic dibasic proprotein processing in maturation of secretory proteins in Trichoderma reesei. Applied and environmental microbiology. 1998;64:3202-8.

Gruber F, Visser J, Kubicek CP, de Graaff LH. The development of a heterologous transformation system for the cellulolytic fungus Trichoderma reesei based on a pyrGnegative mutant strain. Current genetics. 1990;18:71-6.

Guangtao Z, Hartl L, Schuster A, Polak S, Schmoll M, Wang T, et al. Gene targeting in a nonhomologous end joining deficient Hypocrea jecorina. Journal of biotechnology. 2009;139:146-51.

Guangtao Z, Seiboth B, Wen C, Yaohua Z, Xian L, Wang T. A novel carbon source-dependent genetic transformation system for the versatile cell factory Hypocrea jecorina (anamorph Trichoderma reesei). FEMS Microbiological Letters. 2010;303:26-32. 
Harkki A, Mantyla A, Penttila M, Muttilainen S, Buhler R, Suominen P, et al. Genetic engineering of Trichoderma to produce strains with novel cellulase profiles. Enzyme and microbial technology. 1991;13:227-33.

Hartl L, Seiboth B. Sequential gene deletions in Hypocrea jecorina using a single blaster cassette. Current genetics. 2005;48:204-11.

Hazell BW, Te'o VS, Bradner JR, Bergquist PL, Nevalainen KM. Rapid transformation of high cellulase-producing mutant strains of Trichoderma reesei by microprojectile bombardment. Letters in applied microbiology. 2000;30:282-6.

He R, Zhang C, Guo W, Wang L, Zhang D, Chen S. Construction of a plasmid for heterologous protein expression with a constitutive promoter in Trichoderma reesei. Plasmid. 2013;70:425-9.

Herrera-Estrella A, Goldman GH, Van Montagu M. High-efficiency transformation system for the biocontrol agents, Trichoderma spp. Molecular microbiology. 1990;4:839-43.

Hong J, Tamaki H, Kumagai H. Cloning and functional expression of thermostable betaglucosidase gene from Thermoascus aurantiacus. Applied microbiology and biotechnology. 2007;73:1331-9.

Hynes MJ, Pateman JA. The genetic analysis of regulation of amidase synthesis in Aspergillus nidulans. II. Mutants resistant to fluoroacetamide. Molecular and General Genetics. 1970;108:107-16.

Jin X, Xia L. Heterologous expression of an endo- $\beta$-1,4-glucanase gene from the anaerobic fungus Orpinomyces PC-2 in Trichoderma reesei. World Journal of Microbiology and Biotechnology. 2011;27:2913-20.

Jorgensen MS, Skovlund DA, Johannesen PF, Mortensen UH. A novel platform for heterologous gene expression in Trichoderma reesei (Teleomorph Hypocrea jecorina). Microbial cell factories. 2014;13:33.

Joutsjoki VV. Construction by one-step gene replacement of Trichoderma reesei strains that produce the glucoamylase P of Hormoconis resinae. Current genetics. 1994;26:422-9.

Joutsjoki VV, Kuittinen M, Torkkeli TK, Suominen PL. Secretion of the Hormoconis resinae glucoamylase $\mathrm{P}$ enzyme from Trichoderma reesei directed by the natural and the cbh1 gene secretion signal. FEMS microbiology letters. 1993a;112:281-6.

Joutsjoki VV, Torkkeli TK, Nevalainen KM. Transformation of Trichoderma reesei with the Hormoconis resinae glucoamylase $\mathrm{P}$ (gamP) gene: production of a heterologous glucoamylase by Trichoderma reesei. Current genetics. 1993b;24:223-8. 
Karhunen T, Mantyla A, Nevalainen KM, Suominen PL. High frequency one-step gene replacement in Trichoderma reesei. I. Endoglucanase I overproduction. Molecular \& general genetics : MGG. 1993;241:515-22.

Keranen S, Penttila M. Production of recombinant proteins in the filamentous fungus Trichoderma reesei. Current opinion in biotechnology. 1995;6:534-7.

Kim S, Miasnikov A. Method for introducing nucleic acids into fungal cells. Google Patents; 2010.

Koushki MM, Rouhani H, Farsi M. Genetic manipulation of fungal strains for the improvement of heterologous genes expression (a mini-review). Afr J Biotechnol. 2011;10:7939-48.

Kruszewska JS. Heterologous expression of genes in filamentous fungi. Acta biochimica Polonica. 1999;46:181-95.

Kubodera T, Yamashita N, Nishimura A. Transformation of Aspergillus sp. and Trichoderma reesei using the pyrithiamine resistance gene ( $p t r A$ ) of Aspergillus oryzae. Bioscience, biotechnology, and biochemistry. 2002;66:404-6.

Kuck U, Hoff B. New tools for the genetic manipulation of filamentous fungi. Applied microbiology and biotechnology. 2010;86:51-62.

Kuhls K, Lieckfeldt E, Samuels GJ, Kovacs W, Meyer W, Petrini 0, et al. Molecular evidence that the asexual industrial fungus Trichoderma reesei is a clonal derivative of the ascomycete Hypocrea jecorina. Proceedings of the National Academy of Sciences of the United States of America. 1996;93:7755-60.

Laymon RA, Adney WS, Mohagheghi A, Himmel ME, Thomas SR. Cloning and expression of full-length Trichoderma reesei cellobiohydrolase I cDNAs in Escherichia coli. Applied biochemistry and biotechnology. 1996;57-58:389-97.

Levasseur A, Saloheimo M, Navarro D, Andberg M, Monot F, Nakari-Setala T, et al. Production of a chimeric enzyme tool associating the Trichoderma reesei swollenin with the Aspergillus niger feruloyl esterase A for release of ferulic acid. Applied microbiology and biotechnology. 2006;73:872-80.

Li J, Wang J, Wang S, Xing M, Yu S, Liu G. Achieving efficient protein expression in Trichoderma reesei by using strong constitutive promoters. Microbial cell factories. 2012;11:84.

Li XL, Skory CD, Ximenes EA, Jordan DB, Dien BS, Hughes SR, et al. Expression of an AT-rich xylanase gene from the anaerobic fungus Orpinomyces sp. strain PC-2 in and secretion of the heterologous enzyme by Hypocrea jecorina. Applied microbiology and biotechnology. 2007;74:1264-75. 
Liu M, Sun ZX, Zhu J, Xu T, Harman GE, Lorito M. Enhancing rice resistance to fungal pathogens by transformation with cell wall degrading enzyme genes from Trichoderma atroviride. Journal of Zhejiang University Science. 2004;5:133-6.

Liu T, Wang T, Li X, Liu X. Improved heterologous gene expression in Trichoderma reesei by cellobiohydrolase I gene (cbh1) promoter optimization. Acta biochimica et biophysica Sinica (Shanghai). 2008;40:158-65.

Ma L, Zhang J, Zou G, Wang C, Zhou Z. Improvement of cellulase activity in Trichoderma reesei by heterologous expression of a beta-glucosidase gene from Penicillium decumbens. Enzyme and microbial technology. 2011;49:366-71.

Mach RL, Schindler M, Kubicek CP. Transformation of Trichoderma reesei based on hygromycin B resistance using homologous expression signals. Current genetics. 1994;25:567-70.

Mandels M, Parrish FW, Reese ET. Sophorose as an inducer of cellulase in Trichoderma viride. Journal of Bacteriology 1962;83:400-8.

Mandels M, Reese ET. Induction of cellulase in Trichoderma viride as influenced by carbon sources and metals. Journal of Bacteriology. 1957;73:269-78.

MargollesClark E, Hayes CK, Harman GE, Penttila M. Improved production of Trichoderma harzianum endochitinase by expression in Trichoderma reesei. Applied and environmental microbiology. 1996;62:2145-51.

Martinez D, Berka RM, Henrissat B, Saloheimo M, Arvas M, Baker SE, et al. Genome sequencing and analysis of the biomass-degrading fungus Trichoderma reesei (syn. Hypocrea jecorina). Nature biotechnology. 2008;26:553-60.

Meng F, Wei D, Wang W. Heterologous protein expression in Trichoderma reesei using the cbhII promoter. Plasmid. 2013;70:272-6.

Merino S, Cherry J. Progress and Challenges in Enzyme Development for Biomass Utilization. In: Olsson L, editor. Biofuels: Springer Berlin Heidelberg; 2007. p. 95-120.

Miettinen-Oinonen A, Suominen P. Enhanced production of Trichoderma reesei endoglucanases and use of the new cellulase preparations in producing the stonewashed effect on denim fabric. Applied and environmental microbiology. 2002;68:3956-64.

Miettinen-Oinonen A, Torkkeli T, Paloheimo M, Nevalainen H. Overexpression of the Aspergillus niger $\mathrm{pH} 2.5$ acid phosphatase gene in a heterologous host Trichoderma reesei. Journal of biotechnology. 1997;58:13-20.

Mitsuishi Y, Nitisinprasert S, Saloheimo M, Biese I, Reinikainen T, Claeyssens M, et al. Sitedirected mutagenesis of the putative catalytic residues of Trichoderma reesei cellobiohydrolase I and endoglucanase I. FEBS letters. 1990;275:135-8. 
Miyauchi S, Te'o VS, Jr., Bergquist PL, Nevalainen KM. Expression of a bacterial xylanase in Trichoderma reesei under the egl2 and cbh2 glycosyl hydrolase gene promoters. New biotechnology. 2013;30:523-30.

Miyauchi S, Te'o VS, Nevalainen KM, Bergquist PL. Simultaneous expression of the bacterial Dictyoglomus thermophilum xynB gene under three different Trichoderma reesei promoters. New biotechnology. 2014;31:98-103.

Montenecourt BS, Eveleigh DE. Selective screening methods for the isolation of high yielding cellulase mutants of Trichoderma reesei. Advances in Chemistry. 1979;181:289301.

Mustalahti E, Saloheimo M, Joensuu JJ. Intracellular protein production in Trichoderma reesei (Hypocrea jecorina) with hydrophobin fusion technology. New biotechnology. 2013;30:262-8.

Nakari-Setala T, Penttila M. Production of Trichoderma reesei cellulases on glucosecontaining media. Applied and environmental microbiology. 1995;61:3650-5.

Nevalainen $\mathrm{H}$, Peterson R. Making recombinant proteins in filamentous fungi- are we expecting too much? Frontiers in Microbiology. 2014;5.

Nevalainen KM, Te'o VS, Bergquist PL. Heterologous protein expression in filamentous fungi. Trends in biotechnology. 2005;23:468-74.

Nisizawa T, Suzuki H, Nisizawa K. Catabolite repression of cellulase formation in Trichoderma viride. Journal of biochemistry. 1972;71:999-1007.

Nykanen M, Saarelainen R, Raudaskoski M, Nevalainen K, Mikkonen A. Expression and Secretion of Barley Cysteine Endopeptidase B and Cellobiohydrolase I in Trichoderma reesei. Applied and environmental microbiology. 1997;63:4929-37.

Nyyssonen E, Penttila M, Harkki A, Saloheimo A, Knowles JK, Keranen S. Efficient production of antibody fragments by the filamentous fungus Trichoderma reesei. Bio/technology. 1993;11:591-5.

Paloheimo M, Mantyla A, Kallio J, Suominen P. High-yield production of a bacterial xylanase in the filamentous fungus Trichoderma reesei requires a carrier polypeptide with an intact domain structure. Applied and environmental microbiology. 2003;69:7073-82.

Penttila M, Nevalainen H, Ratto M, Salminen E, Knowles J. A versatile transformation system for the cellulolytic filamentous fungus Trichoderma reesei. Gene. 1987;61:155-64.

Peterson R, Nevalainen $H$. Trichoderma reesei RUT-C30--thirty years of strain improvement. Microbiology. 2012;158:58-68. 
Poidevin L, Levasseur A, Paes G, Navarro D, Heiss-Blanquet S, Asther M, et al. Heterologous production of the Piromyces equi cinnamoyl esterase in Trichoderma reesei for biotechnological applications. Letters in applied microbiology. 2009;49:673-8.

Qin LN, Cai FR, Dong XR, Huang ZB, Tao Y, Huang JZ, et al. Improved production of heterologous lipase in Trichoderma reesei by RNAi mediated gene silencing of an endogenic highly expressed gene. Bioresource technology. 2012;109:116-22.

Reinikainen T, Ruohonen L, Nevanen $\mathrm{T}$, Laaksonen L, Kraulis $\mathrm{P}$, Jones TA, et al. Investigation of the function of mutated cellulose-binding domains of Trichoderma reesei cellobiohydrolase I. Proteins. 1992;14:475-82.

Saarelainen R, Mantyla A, Nevalainen H, Suominen P. Expression of Barley Endopeptidase B in Trichoderma reesei. Applied and environmental microbiology. 1997;63:4938-40.

Saarelainen R, Paloheimo M, Fagerstrom R, Suominen PL, Nevalainen KM. Cloning, sequencing and enhanced expression of the Trichoderma reesei endoxylanase II (pI 9) gene xln2. Molecular \& general genetics : MGG. 1993;241:497-503.

Schuster A, Bruno KS, Collett JR, Baker SE, Seiboth B, Kubicek CP, et al. A versatile toolkit for high throughput functional genomics with Trichoderma reesei. Biotechnology for biofuels. 2012a;5:1.

Schuster A, Tisch D, Seidl-Seiboth V, Kubicek CP, Schmoll M. Roles of protein kinase A and adenylate cyclase in light-modulated cellulase regulation in Trichoderma reesei. Applied and environmental microbiology. 2012b;78:2168-78.

Seiboth B, Ivanova C, Seidl-Seiboth V. Trichoderma reesei: A Fungal Enzyme Producer for Cellulosic Biofuels, Biofuel Production-Recent Developments and Prospects. In: Bernardes DMADS, editor.: InTech; 2011.

Seidl V, Gamauf C, Druzhinina IS, Seiboth B, Hartl L, Kubicek CP. The Hypocrea jecorina (Trichoderma reesei) hypercellulolytic mutant RUT C30 lacks a $85 \mathrm{~kb}$ (29 gene-encoding) region of the wild-type genome. BMC genomics. 2008;9:327.

Smith JL, Bayliss FT, Ward M. Sequence of the cloned pyr4 gene of Trichoderma reesei and its use as a homologous selectable marker for transformation. Current genetics. 1991;19:27-33.

Steiger MG. Molecular tools in Trichoderma genetic studies. In: Mukherjee PK, Horwitz BA, Singh US, Mukherjee M, Schmoll M, editors. Trichoderma: Biology and Applications: CABI; 2013. p. 128-43.

Steiger MG, Vitikainen M, Uskonen P, Brunner K, Adam G, Pakula T, et al. Transformation system for Hypocrea jecorina (Trichoderma reesei) that favors homologous integration and employs reusable bidirectionally selectable markers. Applied and environmental microbiology. 2011;77:114-21. 
Sternberg D, Mandels GR. Induction of cellulolytic enzymes in Trichoderma reesei by sophorose. Journal of Bacteriology. 1979;139:761-9.

Suominen PL, Mantyla AL, Karhunen T, Hakola S, Nevalainen H. High frequency one-step gene replacement in Trichoderma reesei. II. Effects of deletions of individual cellulase genes. Molecular and General Genetics. 1993;241:523-30.

Takada G, Kawaguchi T, Sumitani J, Arai M. Expression of Aspergillus aculeatus No. F-50 cellobiohydrolase I ( $c b h I)$ and beta-glucosidase 1 (bgl1) genes by Saccharomyces cerevisiae. Bioscience, biotechnology, and biochemistry. 1998;62:1615-8.

Tangnu S, Blanch HW, Wilke CR. Enhanced Production of cellulase, hemicullulase, and beta-glucosidase by Trichoderma reesei (Rut-C30). Biotechnology and bioengineering. 1981;33:1837-49.

Te'o VS, Bergquist PL, Nevalainen KM. Biolistic transformation of Trichoderma reesei using the Bio-Rad seven barrels Hepta Adaptor system. Journal of microbiological methods. 2002;51:393-9.

Te'o VS, Cziferszky AE, Bergquist PL, Nevalainen KM. Codon optimization of xylanase gene xynB from the thermophilic bacterium Dictyoglomus thermophilum for expression in the filamentous fungus Trichoderma reesei. FEMS microbiology letters. 2000;190:13-9.

Uzbas F, Sezerman U, Hartl L, Kubicek CP, Seiboth B. A homologous production system for Trichoderma reesei secreted proteins in a cellulase-free background. Applied microbiology and biotechnology. 2012;93:1601-8.

von Ossowski I, Stahlberg J, Koivula A, Piens K, Becker D, Boer H, et al. Engineering the exoloop of Trichoderma reesei cellobiohydrolase, Cel7A. A comparison with Phanerochaete chrysosporium Cel7D. Journal of molecular biology. 2003;333:817-29.

Wang J, Zeng D, Mai G, Liu G, Yu S. Homologous constitutive expression of Xyn III in Trichoderma reesei QM9414 and its characterization. Folia Microbiologica (Praha). 2014;59:229-33.

Xu L, Shen Y, Hou J, Peng B, Tang H, Bao X. Secretory pathway engineering enhances secretion of cellobiohydrolase I from Trichoderma reesei in Saccharomyces cerevisiae. Journal of bioscience and bioengineering. 2014;117:45-52.

Zhang G, Zhu Y, Wei D, Wang W. Enhanced production of heterologous proteins by the filamentous fungus Trichoderma reesei via disruption of the alkaline serine protease SPW combined with a pH control strategy. Plasmid. 2014;71:16-22.

Zhang J, Qu Y, Xiao P, Wang X, Wang T, He F. Improved biomass saccharification by Trichoderma reesei through heterologous expression of lacA gene from Trametes sp. AH28-2. Journal of bioscience and bioengineering. 2012;113:697-703. 
Zhang J, Zhong Y, Zhao X, Wang T. Development of the cellulolytic fungus Trichoderma reesei strain with enhanced beta-glucosidase and filter paper activity using strong artificial cellobiohydrolase 1 promoter. Bioresource technology. 2010;101:9815-8.

Zhong YH, Wang XL, Wang TH, Jiang Q. Agrobacterium-mediated transformation (AMT) of Trichoderma reesei as an efficient tool for random insertional mutagenesis. Applied microbiology and biotechnology. 2007;73:1348-54.

Zou G, Shi S, Jiang Y, van den Brink J, de Vries RP, Chen L, et al. Construction of a cellulase hyper-expression system in Trichoderma reesei by promoter and enzyme engineering. Microbial cell factories. 2012;11:21. 


\section{Figure Legends}

Figure 1. Cassettes used for cbh1 deletion in (A) Rut-C30, (B) QM6a by homologous recombination into $(\mathrm{C})$ the native $\operatorname{cbh} 1$ locus.

Figure 2. Expression vector used in H. jecorina strain, AST871. The selection/expression cassette in this construct contains acetamidase gene (amdS) from A. nidulans for selection of transformants based on their ability to utilize acetamide as the sole nitrogen source. Note that AST871 is resistant to hygromycin B because this selection system was used to delete the $c b h 1$ coding sequence.

Figure 3. Deletion of native pyr4 gene. (A) Schematic of pyr4 deletion strategy. (B) Confirmation by PCR of targeted deletion. Shorter product length (Transformant 1) indicates targeted deletion.

Figure 4. Determining conditions for 5-FOA selection. MA plates with 5-FOA and 10mM uridine. (A) QM6a, initial pH 6.5. (B) pyr4 transformation, initial pH 6.5. (Note: Colonies in (B) were picked before large mycelial mats were produced) (C) QM6a, initial pH 5.5. (D) pyr4 deficient strain, initial pH 5.5.

Figure 5. pyr4 as a bidirectional positive selectable marker. (A) Replacement of $h p h$ with pyr4 cassette. (B) 5-FOA selection for loss of the pyr4 cassette results in a clean deletion at the mus53 locus.

Figure 6. Confirmation of clean deletion at mus53. Shorter PCR product indicates region has been deleted.

Figure 7. Expression vector for use in cbh14 strain AST1116. The selection of transformants in this system is based on the expression of bacterial hygromycin phosphotransferase gene $(h p h)$ conferring resistance to hygromycin B. The expression cassette is bound by 2,500 bp of sequence $5^{\prime}$ to $c b h 1$ and $1,500 \mathrm{bp}$ of sequence $3^{\prime}$ to $c b h 1$. This allows for integration of the expression cassette to the $c b h 1$ region by homologous recombination. 
Figure 8. Deletion of mus53 to reduce Non-homologous End Joining (NHEJ) . (A) Schematic of crossover. (B) Confirmation of deletion by PCR of selected transformants.

Figure 9. Cel7A expression in $c b h 1 \Delta$ strains transformed with $c b h 1$ expression constructs. $\alpha$-cel7a immunoblot of a PAGE gel using culture supernatants. 1: Purified Cel7 A; 2: Rut-C30;

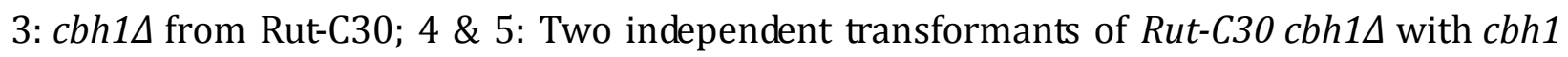
expression construct; 6: QM6a 7: cbh14 from QM6a; 8 \& 9: Two independent transformants of QM6a $c b h 1 \Delta$ with $c b h 1$ expression construct.

Figure 10. Phenotypes of the parent (QM6a), $c b h 1 \Delta$ and $\alpha$ cbh1-targeted transformant. QM6a, (A); deletion strain derived from QM6a, AST1116, (B) and a transformant in which an expression system has been integrated at the $c b h 1$ locus (C). 
Figure 1.

A) $c b h / \Delta:: h p h$ (RUT-C30)

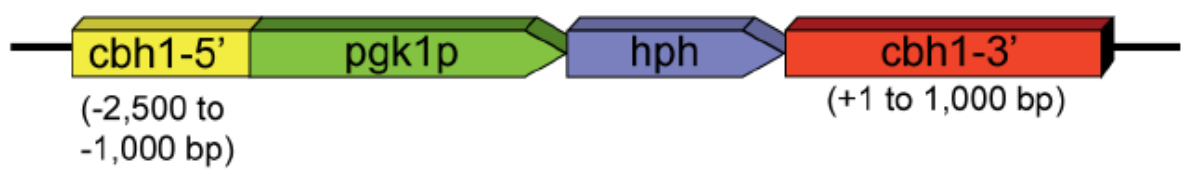

B) $c b h / \Delta:: a m d S$ (QM6a)

\begin{tabular}{|c|c|c|}
\hline cbh1-5 & pgk1p $>$ amdS $>$ & cbh1-3' \\
\hline $\begin{array}{l}(-2,500 \text { to } \\
-1,000 \text { bp })\end{array}$ &
\end{tabular}

C) Native locus

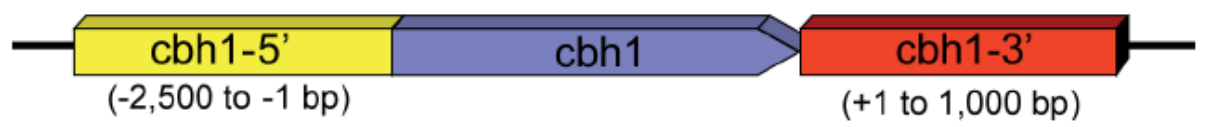


Figure 2

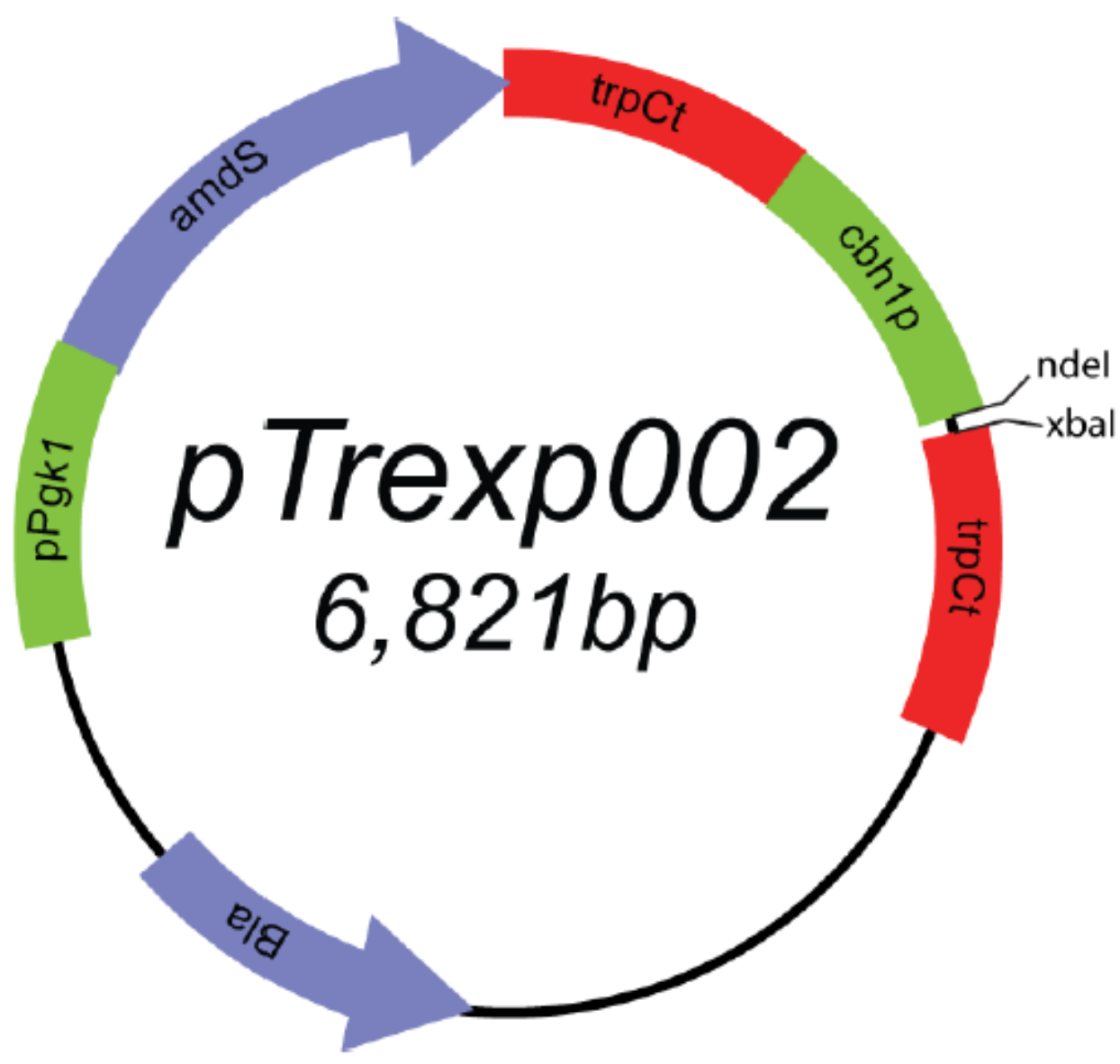


Figure 3

A.

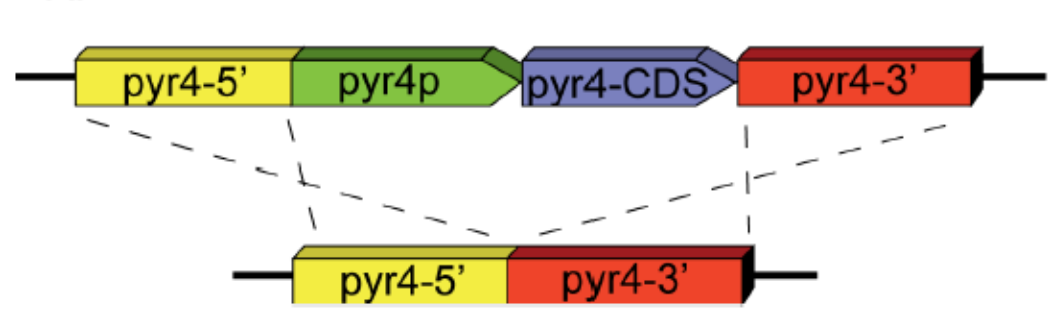

B.

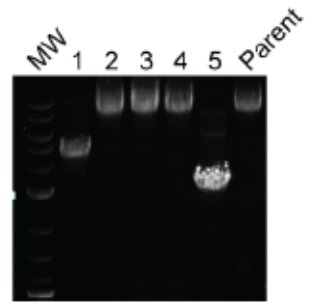


Figure 4

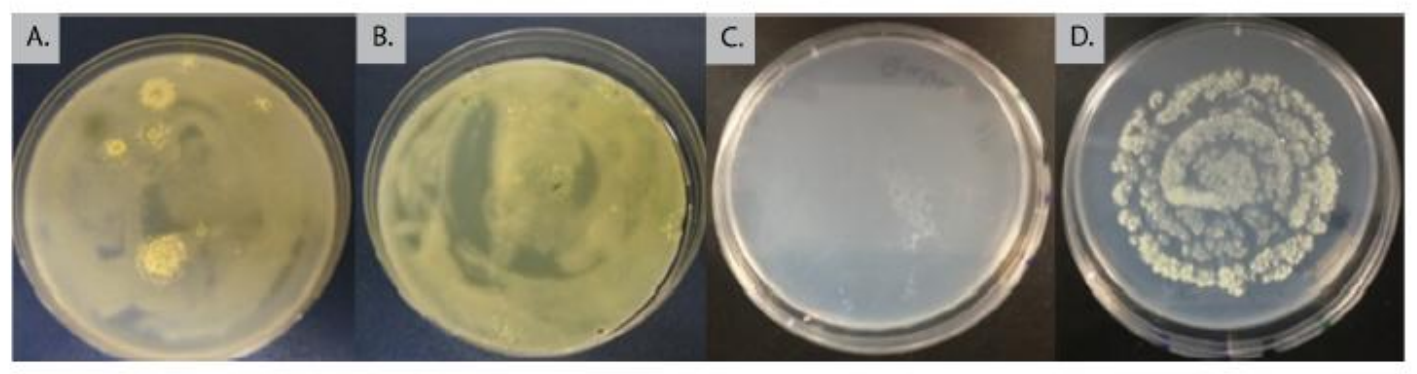


Figure 5

A.

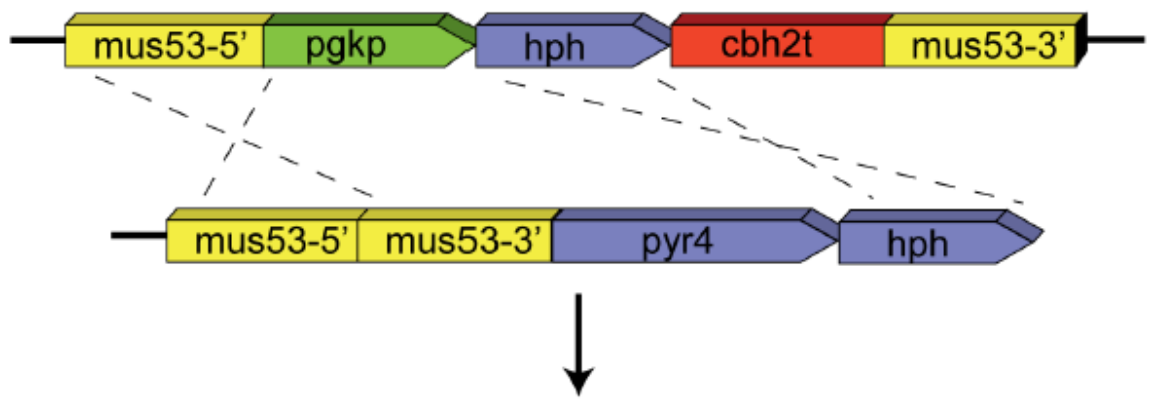

B.

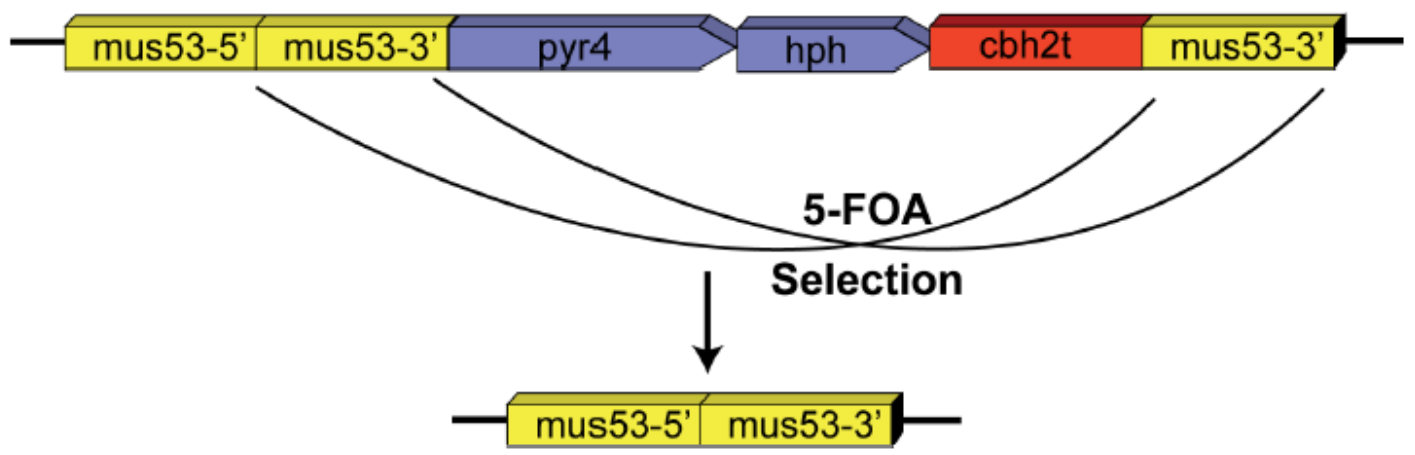


Figure 6

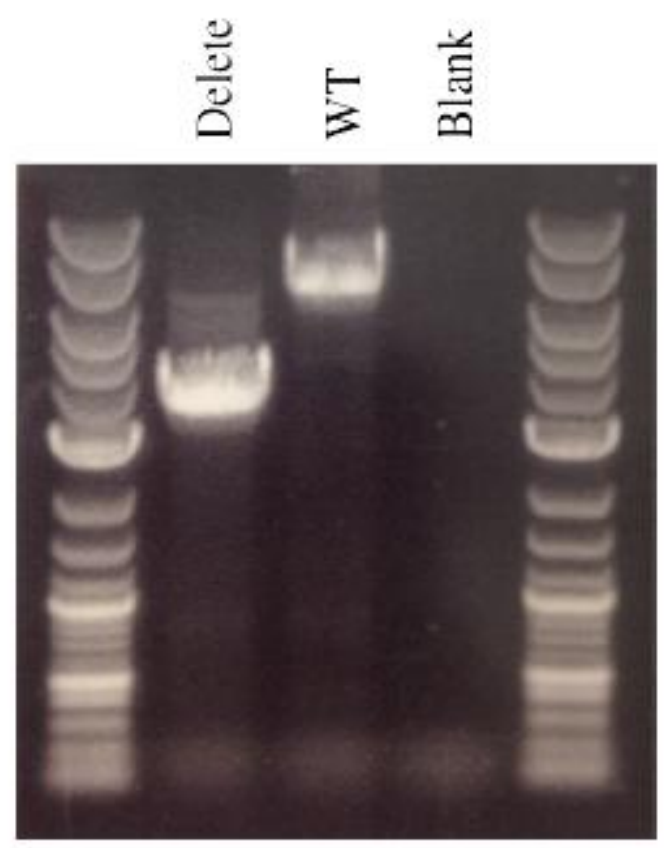


Figure 7

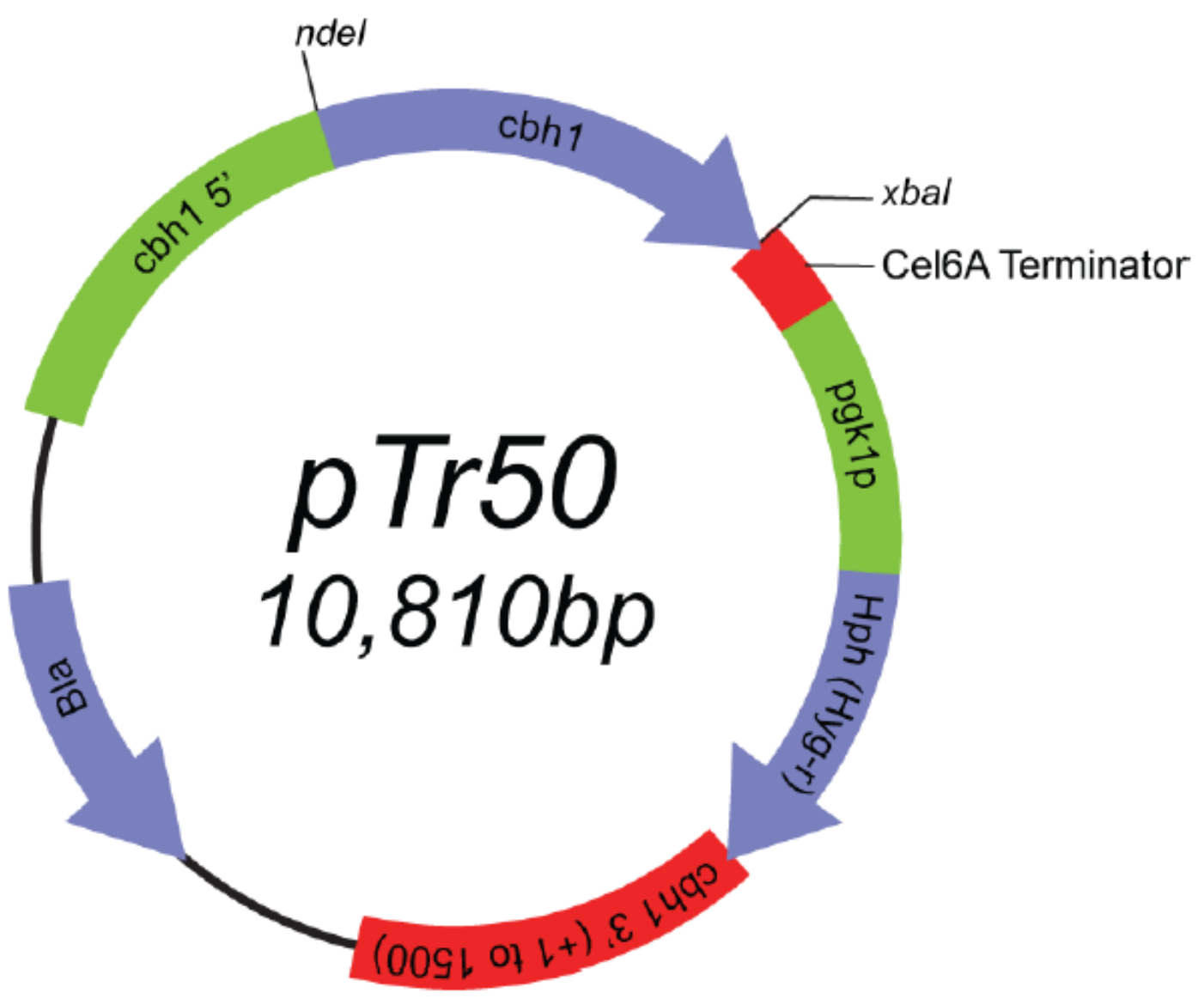


Figure 8

A.

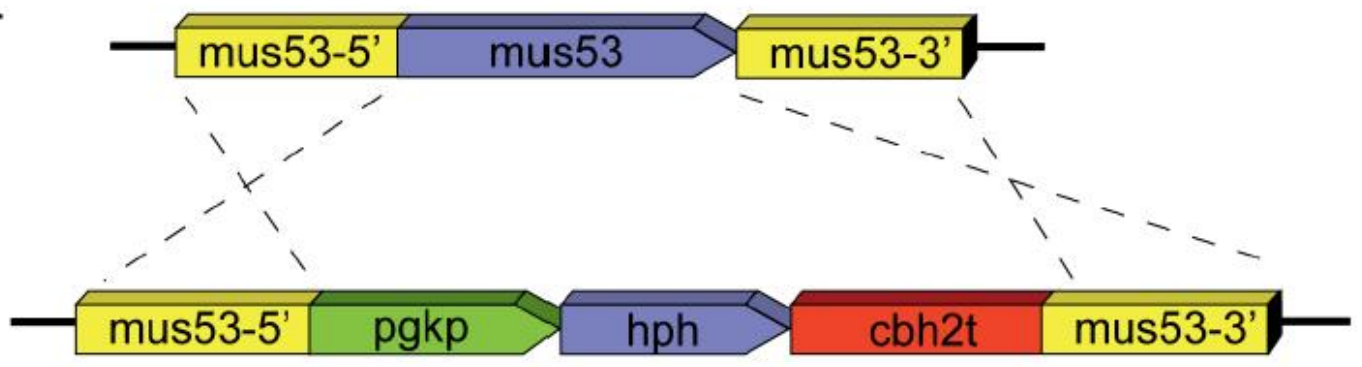

B.

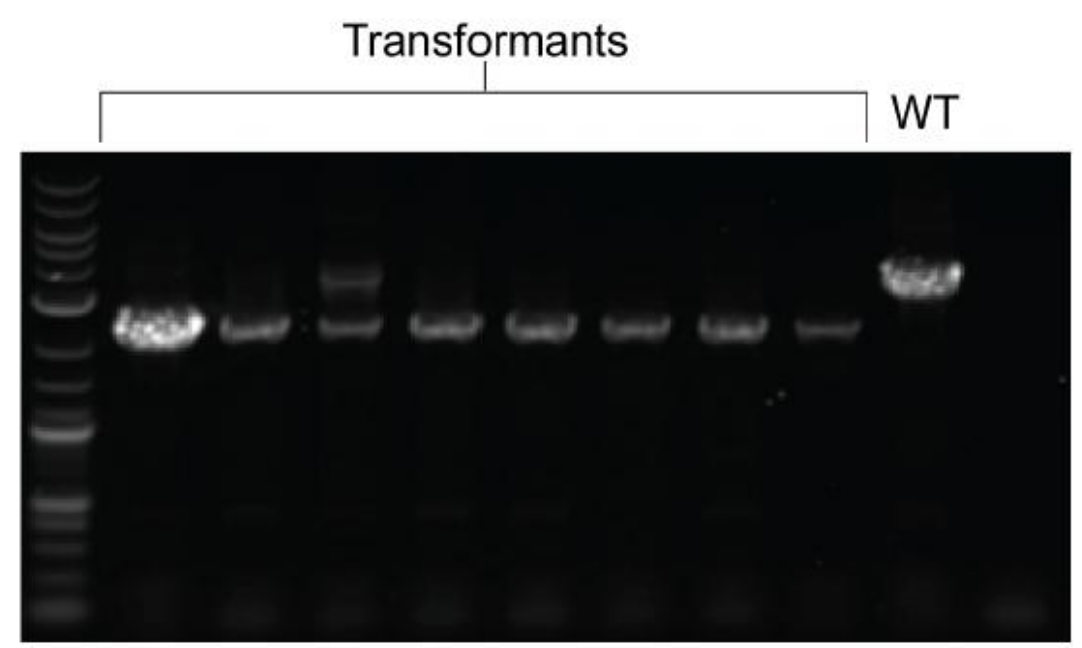


Figure 9

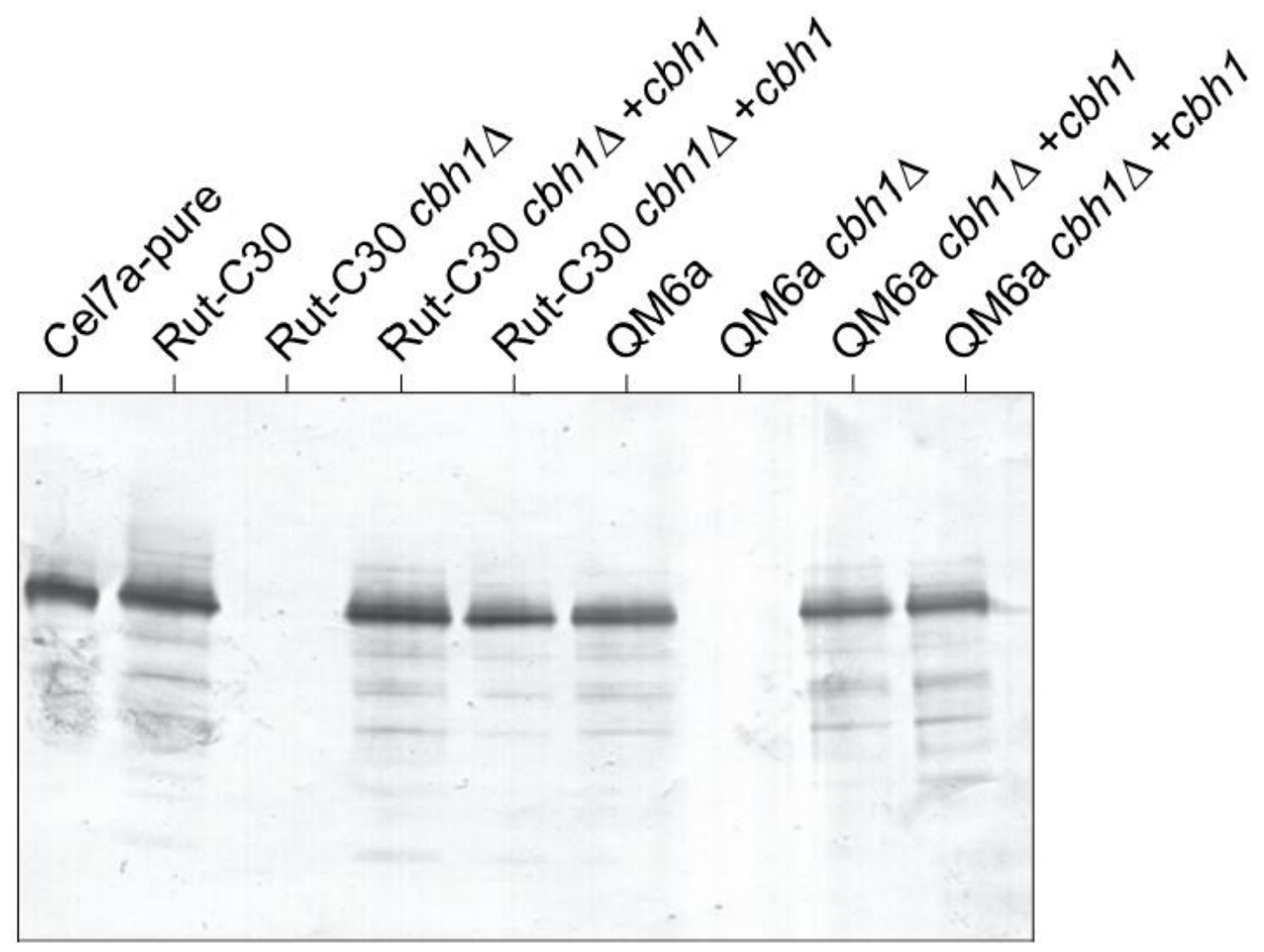


Figure 10

A.

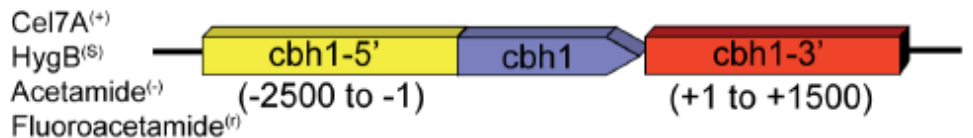

B.

Cel7A $A^{(-)}$

\begin{tabular}{|l|l|} 
HygB $^{(s)}$ \\
Acetamide $^{(+)}$
\end{tabular} \begin{tabular}{|c|c|}
\hline cbh1-5' & pgk1p \\
\hline
\end{tabular}

Fluoroacetamide $^{(s)}$

C.

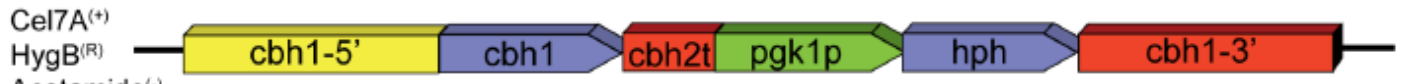

Acetamide(-)

Fluoroacetamide ${ }^{(n)}$ 
Table 1. Hypocrea jecorina strains used in heterologous protein expression

\begin{tabular}{|c|c|c|c|c|}
\hline Strain ID & Geno/Phenotype & Purpose & Source & Reference(s) \\
\hline $\begin{array}{l}\text { QM6a } \\
\text { (VTT-D-74083T) } \\
\text { (VTT-D-021262T) } \\
(\text { IF0/NBRC31326) }\end{array}$ & Wild-type & General protein expression & $\begin{array}{l}\text { ATCC } \\
\text { VTT } \\
\text { VTT } \\
\text { (NBRC) }\end{array}$ & (Kubodera et al., 2002) \\
\hline $\begin{array}{l}\text { QM9414 } \\
\text { (VTT-D-74075) }\end{array}$ & $\begin{array}{l}\text { Hypersecreting mutant } \\
\text { of QM6a }\end{array}$ & $\begin{array}{l}\text { High yield general expression } \\
\text { synergy studies with induced } \\
\text { cellulase background }\end{array}$ & ATCC & $\begin{array}{l}\text { (Bailey et al., 2002, Dashtban and Qin, 2012, Fu et al., } \\
\text { 2010, Guangtao et al., 2009, Mach et al., 1994, Penttila } \\
\text { et al., 1987, Wang et al., 2014, Zhong et al., 2007) }\end{array}$ \\
\hline $\begin{array}{l}\text { RUT-C30 } \\
\text { (VTT-D-86271) }\end{array}$ & $\begin{array}{l}\text { Catabolite de-repressed, } \\
\text { hypersecreting mutant } \\
\text { of QM6a }\end{array}$ & $\begin{array}{l}\text { High yield general expression } \\
\text { Synergy studies with } \\
\text { constitutive cellulase } \\
\text { background }\end{array}$ & ATCC & $\begin{array}{l}\text { (Bailey et al., 2002, Hazell et al., 2000, Joutsjoki et al., } \\
\text { 1993b, Kautto et al., 2013, Murray et al., 2004, } \\
\text { Nykanen et al., 1997, Peterson and Nevalainen, 2012, } \\
\text { Saarelainen } \text { et al., 1997, Salles et al., 2007) }\end{array}$ \\
\hline RUT-C30 M3 & $\begin{array}{l}\text { Protease deficient strain } \\
\text { of RUT-C } 30\end{array}$ & General protein expression & Shandong U & (Liu et al., 2008) \\
\hline CL847 & $\begin{array}{l}\text { High cellulase } \\
\text { production mutant } \\
\text { derived from QM9414 }\end{array}$ & General protein expression & & (Levasseur et al., 2006) \\
\hline TU-6 ${ }^{2}$ & $\begin{array}{l}\Delta \square \square \square \square \text { derived from } \\
\text { QM9414 }\end{array}$ & ura auxotroph selection & TU Wein & $\begin{array}{l}\text { (Gruber et al., 1990, Guangtao et al., 2009, Mach et al., } \\
\text { 1994) }\end{array}$ \\
\hline TU-6H ${ }^{2}$ & $\Delta \square \square \square \iota$ in TU-6 & Hexokinase selection & Shandong U & (Guangtao et al., 2010) \\
\hline KU70.4 2 & $\Delta \square \square \square \tilde{\square}$ in TU-6 & $\begin{array}{l}\text { Non-homologous end-joining } \\
\text { mutant }\end{array}$ & $\begin{array}{l}\text { TU Wein } \\
\text { Shandong U }\end{array}$ & (Guangtao et al., 2009) \\
\hline VTT-D-78085 & $\begin{array}{l}\beta \text {-G hyperproducer } \\
\text { derived from QM9414 }\end{array}$ & & VTT & (Nevalainen et al., 1980) \\
\hline VTT-D-93201 & $\begin{array}{l}\Delta c b h 1, \operatorname{amdS}(+) \text { derived } \\
\text { from QM9414 }\end{array}$ & Expression of Cel7A & VTT & (Reinikainen et al., 1995, Stahlberg et al., 1996) \\
\hline VTT-D-79125 & $\begin{array}{l}\text { High cellulase } \\
\text { production mutant }\end{array}$ & $\begin{array}{l}\text { General expression, gene } \\
\text { knockout studies }\end{array}$ & VTT & $\begin{array}{l}\text { (Bailey and Nevalainen, 1981, Harkki et al., 1991, } \\
\text { Hazell et al., 2000, Karhunen } \text { et al., 1993, Mantyla et }\end{array}$ \\
\hline
\end{tabular}




\begin{tabular}{|c|c|c|c|c|}
\hline & derived from QM9414 & & & $\begin{array}{l}\text { al., 1992, Penttila et al., 1987, Saarelainen et al., 1993, } \\
\text { Suominen et al., 1993a, b, Te'o et al., 2002) }\end{array}$ \\
\hline GC69 & $\begin{array}{l}\square \square \square \square \text { in an RL-P37 } \\
\text { background }\end{array}$ & ura auxotroph selection & Genencor & (Smith et al., 1991) \\
\hline PTUC1 $^{2}$ & $\begin{array}{l}\Delta \square \square \square \square \text { derived from } \\
\text { QM9414 }\end{array}$ & General protein expression & U Bordeaux & (Berges and Barreau, 1991) \\
\hline $\begin{array}{l}\text { VTT-D-87305 } \\
\text { VTT-D-87307 }\end{array}$ & $\begin{array}{l}\arg (-) \text { derived from VTT- } \\
\text { D-79125 }\end{array}$ & General protein expression & VTT & (Penttila et al., 1987) \\
\hline HEP1 & $\begin{array}{l}\text { Protease-deficient, high } \\
\text { enzyme secretion, derived } \\
\text { from VTT-D-79125 }\end{array}$ & General protein expression & VTT & (de Faria et al., 2002, Te'o et al., 2000) \\
\hline ALK03414 3 & $\operatorname{cbh} 1(-), \operatorname{cbh} 2(-)$ & Expression of Cel7A, Cel6A & $\begin{array}{l}\text { Primalco, } \\
\text { Ltd. }\end{array}$ & (von Ossowski et al., 2003) \\
\hline ALKO2221 3 & $\begin{array}{l}\text { Low aspartyl protease } \\
\text { mutant of VTT-D-79125 }\end{array}$ & Increased protein yield & Alko, Ltd & $\begin{array}{l}\text { (Hazell et al., 2000, Joutsjoki et al., 1993b, Saarelainen } \\
\text { et al., 1997, Saarelainen et al., 1993) }\end{array}$ \\
\hline ALKO27213 & $\begin{array}{l}\operatorname{Trp} C^{+} \text {into } \Delta c b h 2 \text { in VTT } \\
\text {-D-79125 background }\end{array}$ & $\begin{array}{l}\text { General expression w/ AmdS } \\
\text { selection }\end{array}$ & Alko, Ltd & (Saarelainen et al., 1993) \\
\hline ALK03620 & $\operatorname{cel} 5 a(-)$ & General protein expression & & (Paloheimo et al., 2003) \\
\hline ALK04468 & $\operatorname{cel} 5 a(-) \operatorname{cel} 7 b(-)$ & General protein expression & & (Paloheimo et al., 2003) \\
\hline $\mathrm{ZU}-02^{2}$ & $\begin{array}{l}\text { Mutant (unclear } \\
\text { phenotype) derived } \\
\text { from ATCC } 56764\end{array}$ & $\begin{array}{l}\text { General expression through } \\
\text { Agrobacterium-mediated } \\
\text { transformation }\end{array}$ & $\begin{array}{l}\text { Zhejiang } \\
\text { University }\end{array}$ & $\begin{array}{l}\text { (Fang and Xia, 2013, Liming and Xueliang, 2004, Ma et } \\
\text { al., 2011) }\end{array}$ \\
\hline AST871 & $\Delta c b h 1, h p h+$ in Rut-C30 & $\begin{array}{l}\text { Expression of Cel7A in high } \\
\text { cellulase producing strain }\end{array}$ & NREL & This study \\
\hline AST1116 & $\Delta c b h 1, a m d S+$ in $\mathrm{QM} 6 \mathrm{a}$ & $\begin{array}{l}\text { Expression of Cel7A in native } \\
\text { strain }\end{array}$ & NREL & This study \\
\hline
\end{tabular}

